Rakenteiden Mekaniikka (Journal of Structural Mechanics)

vol. 53, nro. 3, 2020, s. 208-239

http://rakenteidenmekaniikka.journal.fi/index

https://doi.org/10.23998/rm.79336

(C) 2020 kirjoittajat

vapaasti saatavilla CC BY 4.0 -lisenssin mukaisesti

\title{
Laivojen pohjien likaantumisen vaikutus kulkuvastukseen Itämerellä: teoreettinen viitekehys ja empiiriset mittaukset
}

\author{
Elias Altarriba
}

Tiivistelmä COMPLETE-hankkeen tavoitteena on tuottaa päätöksenteon tueksi optimointityökalu, minkä avulla voidaan hallita laivojen pohjien likaantumisesta aiheutuvia haittoja. Työkalussa on useita osa-alueita, joista toiset tarkastelevat ilmiötä esimerkiksi vieraslajien leviämisen tai pintakäsittelymateriaalien myrkyllisyyden näkökulmasta. Yhtenä osa-alueena on alusten kulkuvastusten muutokset pohjan likaantumisasteen seurauksena. Tässä artikkelissa käsitellään menetelmiä, joilla alusten kulkuvastusta voidaan laskennallisesti mallintaa sellaisilla lähtötiedoilla, jotka todennäköisesti olisivat työkalun käyttäjien saatavissa. Laskennallisia tuloksia verrataan operoinnin aikana mittaamalla saatuihin arvoihin. Tavoitteena on havainnoida erityisesti vaikeasti mallinnettavissa olevien muuttujien, kuten sääolosuhteiden, vaikutusta aluksen kulkuun ja näin arvioida tarpeita työkalun jatkokehityksen suhteen.

Avainsanat: COMPLETE, laivaliikenne, pohjan likaantuminen, Itämeri

Vastaanotettu: 11.2.2019. Hyväksytty: 31.5.2019. Julkaistu verkossa: 3.7.2020.

\section{Johdanto}

COMPLETE on Interreg Baltic Sea Region -ohjelman puitteissa vuosina 2017-2020 toteutettava Euroopan aluekehitysrahaston rahoittama lippulaivahanke [1]. Hankkeen partnerit ovat yliopistoja, tutkimuslaitoksia tai muita instituutioita Itämeren rantavaltioista lukuun ottamatta Tanskaa ja Venäjää. Tutkimushankkeen päätavoitteena on tutkia merellisten vieraslajien leviämistä Itämeren alueella. Haitalliset vieraslajit voivat levitessään uusille alueille pahimmillaan muuttaa merkittävästi uuden alueen ekosysteemiä aiheuttaen näin merkittäviä ympäristöhaittoja tai taloudellisia vahinkoja. Laivojen painolastivesien mukana tapahtuvaa vieraslajien leviämistä on tutkittu maailmanlaajuisesti paljon [2, 3] ja tutkimustietoon monilta osin perustuva IMO:n vuonna 2004 hyväksymä kansainvälinen painolastivesiyleissopimus [4] astui kansallisten ratifiointien jälkeen voimaan 7. syyskuuta 2017 [5]. Sopimus muun muassa määrää aluksille pakollisiksi painolastivesien käsittelylaitteistot ja asettaa lukuisia rajoituksia painolastivesien vaihdolle. 
Eliö- tai levälajikkeita, jotka mahdollisesti leviävät merialueelta toiselle kiinnittyneinä alusten vedenalaisiin rakenteisiin, on tutkittu huomattavasti vähemmän. Erityisesti lämpimillä merialueilla pidempiä satamajaksoja viettävien alusten runkojen likaantuminen biologisesta aineksesta kasvattaisi aluksen kulkuvastusta merkittävästi ilman kasvuston kiinnittymisen torjuntamenetelmiä. Aluksen siirtyessä toiselle merialueelle kulkeutuvat runkoon kiinnittyneet eliöt aluksen mukana ja erityisesti puhdistettaessa aluksen pohjaa uudessa ympäristössä siitä irtoaa paljon biologista ainesta, jolloin muodostuu reitti monien lajikkeiden leviämiselle. Alusten pohjien likaantumista ehkäistään valitsemalla olosuhteisiin soveltuva pintakäsittelymenetelmä [6]. Erityisesti kuparia sisältävät myrkkymaalit ovat olleet tehokkaita kasvuston kertymisen estäjiä, mutta ne aiheuttavat ympäristöhaittoja veteen liukenevien myrkkyjen muodossa [7, 8]. Tämän takia monien alusten rungot käsitellään nykyään kuparivapailla AF- tai FR- tyyppisillä (antifouling tai foul release) pintakäsittelymenetelmillä, jotka pyrkivät olemaan mahdollisimman huono alusta kasvuston ja eliöstön kiinnittymisille tai jotka omaavat itsekiillottumisominaisuuksia irrottaen samalla pintaan jo kiinnittynyttä biomassaa [9].

Vedenalaisten runkorakenteiden likaantuminen kasvattaa laivojen kulkuvastusta [10]. Likaantumisen vaikutus aluksen hydrodynamiikkaan on ilmiönä havaittu jo varhain [11], sillä pahasti likaantunut pohja kasvattaa kulkuvastusta pahimmillaan kymmeniä prosentteja [12]. Aiemmin meriliikenteen polttoaineiden edullisuuden vuoksi asiaan on kuitenkin suhtauduttu varsin suurpiirteisesti [13]. Myrkkymaalattuja pohjia on putsattu arvioidun tarpeen mukaan tai ainoastaan telakointien yhteydessä, ja monet Itämeren alueella toimineet varustamot ovat luottaneet jäiden kykyyn kaapia kesäkaudella pohjaan kertynyt kasvusto irti aluksesta. Sittemmin tarpeet vähentää Itämeren kemiallista kuormitusta, laivapolttoaineiden epävakaampi hintakehitys ja niiden kasvaneet laatuvaatimukset ovat pakottaneet monet varustamot etsimään säästömahdollisuuksia muun muassa kiinnittämällä enenevästi huomiota pohjan puhtauteen. Pakokaasupäästöjen osalta asiaan liittyy myös ilmastollinen aspekti. On todennäköistä, että tulevaisuudessa nähdään painolastivesiyleissopimuksen tai EU:n rikkidirektiivin kaltaisia ratkaisuja sopia meriliikenteen globaalin ympäristökuormituksen vähentämisestä laajemmin.

Alusten pohjien likaantumisen vaikutusten tieteellisen tutkimuksen uranuurtajia ovat olleet William Froude [14, 15] ja McEntee [16]. Frouden tutkimuksissa on perehdytty pohjan karheuden kulkuvastusta lisäävän vaikutuksen arviointiin. McEnteen kokeellisessa tutkimuksessa on testattu eri tavoin pintakäsiteltyjen levyjen kontaminoitumista ja sen vaikutusta virtausvastukseen. Höyrykoneaikakausi, säännöllisesti valtameret ylittävä laivaliikenne ja rautarunkojen yleistyminen vauhdittivat merkittävästi laivahydrodynamiikan kehitystä, tosin alusten pohjien puhtauteen kiinnitettiin huomiota myös purjelaiva-aikakaudella. Esimerkiksi kuparipohjaisten maalien kasvuston kiinnittymistä ehkäisevä vaikutus on tunnettu jo antiikin aikana [13]. Kempfin [17] ja Bensonin [18] empiirisissä kokeissa perehdyttiin merirokon kaltaisten äyriäisten aiheuttamaan kulkuvastuslisään niiden peittävyyden ja kokoluokan funktiona. Wanataben [19] tutkimuksissa ilmiötä on tutkittu mallikokein, Loeb [20] on toteuttanut virtausvastustestejä pyörivin kiekoin, ja Lewkowicz ja Das ovat tehneet vastaavia kokeita käyttäen uittolevyjä [21]. Erilaisten levä- ja eliökerrostumien kulkuvastusta lisäävän vaikutuksen osalta tutkimustyötä ovat tehneet muun muassa Schultz et al. [22-24]. Pääosa tutkimuksesta on tehty laboratorio-olosuhteissa [25, 26], sillä todellisilla laivoilla tehtävä tutkimus sisältää lukuisia virhelähteitä; kuten syväyden ja trimmin muutokset, sääolosuhteet (tuulet ja aallot), merivirrat, meren lämpötilan ja suolapitoisuuden vaihtelut [27-29]. 
Laboratoriokokeista saatujen tulosten skaalautuvuus todellisen kokoluokan laivoihin huomioiden laivan runkorakenteiden pintakäsittelymenetelmät ovat tulosten sovellettavuuden kannalta kriittinen kysymys. Granvillen skaalauskertoimien soveltuvuutta pohjan karheuden vaikutusten arviointiin ovat tutkineet Schultz [30], Flack ja Schultz [31] ja Turan et al. [32]. Demirelin ym. [33, 34] CFD-laskentaa soveltavaa analyysiä konttialuksen kulkuvastuksen muutokseen pohjan likaantumisen seurauksena on jatkettu Oliveiran et al. [13] työssä, jossa perehdytään aluksen rungon muodon, rungon karheuden ja laboratoriotestien vertailtavuuteen.

COMPLETE-hankkeen yksi konkreettinen tavoite on luoda päätöksenteon tueksi optimointityökalu varustamojen, viranomaisten, tutkimuslaitosten ja muiden toimijoiden käyttöön [1]. Työkalun tavoitteena on tarjota sitä käyttäville osapuolille tutkimukseen perustuvaa, mutta helpommin sovellettavissa olevaa tietoa pohjan likaantumisen vaikutuksista kulkuvastukseen, vieraslajien leviämiseen ja toiminnasta aiheutuneisiin ympäristövaikutuksiin. Tutkimustulosten jalkauttaminen Itämeren toimijoille tapahtuu hankkeessa partnerina olevan HELCOM:in (Helsingin komissio) välityksellä.

Optimointityökalu pitää sisällään useita elementtejä. Osa niistä tarkastelee asiaa ainoastaan biologisen viitekehyksen kautta, osa huomioi muun muassa toiminnan arvioidut taloudelliset vaikutukset. Työkalun yhden elementin tehtävänä on arvioida alusten runkorakenteiden biologisen likaantumisen seurauksena lisääntyvää kulkuvastusta ja sen kerrannaisvaikutuksia. Tavoitteena on tuottaa konkreettista, aluskohtaista tietoa, minkä avulla työkalun käyttäjä voi arvioida likaantumisen vaikutuksia esimerkiksi polttoaineenkulutukseen, nopeuteen tai päästöihin.

Optimointityökalussa laivojen hydrodynaamisia kulkuvastuksia mallintavalle teoreettiselle viitekehykselle asetetaan muun muassa seuraavia vaatimuksia: Lähtöarvojen on oltava työkalun käyttäjien saatavissa ja sen on mahdollistettava erilaisten alustyyppien mallintaminen kohtuullisella tarkkuudella. Helsingin komission käyttämässä alustyyppiluokituksessa kauppa-alukset jaetaan tankkereihin, lastialuksiin, konttialuksiin, matkustaja-aluksiin, RORO/ROPAX-aluksiin, huoltoaluksiin, kalastusaluksiin ja muun tyyppisiin aluksiin [35]. Käytännössä kuitenkin esimerkiksi tankkeriluokassa alustyypistä riippuen niiden pohjarakenteet ja -muodot voivat vaihdella merkittävästi. Ensivaiheessa oleellista on keskittyä kulkuvastuksen tarkasteluun aluksen normaalilla matkanopeudella. Muuttujia tällaisessa lähestymistavassa on kuitenkin paljon: Aluksen operoinnista suoraan aiheutuvat muutokset (nopeus, ohjailu, vakaajat, potkureiden lapakulmat, moottoreiden tuottama teho), muutokset syväyksessä, märkäpinta-alassa, trimmissä ja DWT:ssä, merenkäynti mahdollisine virtauksineen, tuuli- ja sääolosuhteet, merenpohjaefekti operoitaessa matalassa vedessä, sekä akseligeneraattoreiden ja muiden apulaitteiden aiheuttamat mahdolliset kuormitusmuutokset pääkoneille [36-41].

Tässä artikkelissa perehdytään menetelmiin, millä laivojen kulkuvastusta voidaan mallintaa työkalulle asetettujen vaatimusten edellyttämällä tavalla. Käsitellyt menetelmät mallintamat pohjan likaantumisen pinnankarheuden kasvamisena. Teoreettisen viitekehyksen antamia tuloksia verrataan kulussa olevalta alukselta tallennettuun dataan, jotta voidaan havainnoida operointiolosuhteissa käytännössä tapahtuvien muutosten suuruusluokka. Työkalun jatkokehityksen kannalta tämä on oleellista, sillä määräajoin tehtävien puhdistusten ja pohjan likaantumista ehkäisevien pintakäsittelymenetelmien seurauksena oletetut muutokset kulkuvastuksen lisääntymisessä jäävät todennäköisesti alle $5 \%$. 


\section{Teoreettinen viitekehys}

Optimointityökalun on kyettävä mallintamaan aluksen kulkuvastusta tarkoitukseen sopivalla tarkkuudella huomioiden pohjan likaantumisaste. Lisäksi teoreettisen viitekehyksen lähtöarvojen on oltava työkalun käyttäjien selvitettävissä. Ensimmäisessä versiossa kulkuvastukset simuloidaan hyödyntäen ITTC-78:n laskentamalleja soveltuvin osin [36, 37]. Viskoottisen vastuksen osalta testataan lisäksi Grigsonin esittämää menetelmää simuloida kitkavastusta Reynoldsin luvun funktiona [41, 42]. Aaltovastus mallinnetaan Taylorin-Gertlerin ja Harvaldin-Guldhammerin jäännösvastusyhtälöllä $[40,43,44]$ huomioiden bulbin vastusta vähentävä vaikutus erillisellä kertoimella [36, 37]. Aluksen vedenalaisen rungon likaantumisen oletetaan fysikaalisesti kasvattavan pohjan pinnankarheutta. Luodun mallin antamia tuloksia verrataan oikealta alukselta tallennettuun kulkudataan tarkoituksena testata mallin luotettavuutta ja erityisesti arvioida aluksen operointiolosuhteiden vaikutusta laskennallisiin tuloksiin. Tallennettu data sisältää operoinninaikaiset tiedot syväyksestä, trimmistä, potkureiden lapakulmista, akselitehoista, polttoaineen kulutuksesta ja aluksen nopeudesta pohjan suhteen. Aluksen muut tekniset tiedot ja matkakohtainen alukselta ilmoitettu omapaino saadaan varustamolta (taulukko 1). HELCOM tuottaa AIS-datatallenteen aluksen sijainnista. Säätilan arviointi perustuu reitin varrella sijaitsevien rannikkosääasemien (Ristna, Gotska Sandön, Östergarnsholm, Hoburg, Ölands Södra Udde, Utklippan, Skillinge) tallenteisiin. Virtausennusteet tuottaa Saksan liittovaltion liikenne- ja viestintäministeriön alainen merenkulun ja hydrologian virasto BSH (Bundesamt für Seeschifffahrt und Hydrographie).

Taulukko 1. Aluksen fysikaaliset suureet

\begin{tabular}{ll}
\hline Suure & Symboli \\
\hline Vesilinjan pituus & $\mathrm{L}_{\mathrm{wl}}$ \\
Hydrodynaaminen pituus & $\mathrm{L}_{\mathrm{os}}$ \\
Perpendikkelipituus & $\mathrm{L}_{\mathrm{pp}}$ \\
Leveys & $\mathrm{B}$ \\
Syväys & $\mathrm{T}$ \\
Korkeus & $\mathrm{H}$ \\
Runkopaino & $\mathrm{W}_{\text {alus }}$ \\
Omapaino & $\mathrm{DWT}$ \\
Uppouma & $\mathrm{V}$ \\
Keskilaivankaaren ala & $\mathrm{A}$ \\
\hline
\end{tabular}

Aluksen fysikaalisten perussuureiden avulla määritetään uppouman täyteläisyys $\left(C_{b}\right)$, keskilaivankaaren täyteläisyys $\left(C_{m}\right)$, prismaattinen täyteläisyys $\left(C_{p}\right)$ ja uppouman hoikkuusluku $\left(C_{v}\right)$ :

$$
\begin{aligned}
& C_{b}=\frac{V}{L_{o s} B T}, \\
& C_{m}=\frac{A}{B T},
\end{aligned}
$$




$$
\begin{aligned}
& C_{p}=\frac{C_{b}}{C_{m}}, \\
& C_{v}=\frac{V}{L_{o s}^{3}} .
\end{aligned}
$$

Täyteläisyysluvut indikoivat aluksen runkorakenteen hydrodynaamisia ominaisuuksia [38, 40]. Perussuureiden, täyteläisyyslukujen ja pohjan märkäpinta-alan perusteella voidaan mallintaa yleispätevästi rungoltaan erityyppisten alusten synnyttämää kulkuvastusta nopeuden funktiona. Aluksen kulkuvastusteho muodostuu ilmanvastuksesta $\left(F_{v} v_{i l m a}\right)$ ja hydrodynaamisesta vastuksesta $\left(R_{t} v_{n o p}\right)$ :

$$
P_{T}=R_{t} v_{n o p}+F_{v} v_{i l m a}
$$

Aluksen ilmanvastus voidaan yksinkertaisimmillaan arvioida yhtälöllä 6 olettaen, että alus etenee staattisen ilmamassan läpi. Käytännössä tuulet kuitenkin yleensä pyrkivät sortamaan alusta suunnastaan, jolloin ilmanvastus vaikuttaa aluksen kulkuun sekä suoraan että kasvaneen ohjailuvastuksen kautta. Säätilan vaikutus kokonaisuudessaan vaatii kuitenkin tarkempaa tutkimusta, minkä vuoksi ilmanvastuksen osalta tässä vaiheessa sovelletaan yhtälöä:

$$
F_{v}=\frac{1}{2} C_{i l m a} \rho_{i l m a} A_{o t s} v_{i l m a}^{2}
$$

missä $C_{i l m a}$ on aluksen ilmanvastuskerroin, $\rho_{\text {ilma }}$ ilman tiheys, $A_{\text {ots }}$ otsapinta-ala ja $v_{\text {ilma }}$ aluksen ilmanopeus otsapinta-alaa vasten. Hydrodynaamisen kulkuvastuksen $[38,40]$ yhtälö on muotoa

$$
R_{T}=\frac{1}{2} \rho_{\text {vesi }} S C_{T} v_{\text {nop }}^{2},
$$

missä $\rho_{\text {vesi }}$ on meriveden tiheys, $S$ aluksen runkorakenteen märkäpinta-ala, $C_{T}$ hydrodynaamisen vastuksen kerroin ja $v_{\text {nop }}$ aluksen nopeus veden suhteen. Hydrodynaamisen vastuksen kerroin voidaan jakaa seuraaviin komponentteihin:

$$
C_{T}=C_{f}+C_{r}+\Delta C_{f}+\Delta C_{a}+\Delta C_{b l}+\Delta C_{l}
$$

missä $C_{f}$ on kitka- eli viskoottinen vastus, $C_{r}$ jäännös- eli aaltovastus, $\Delta C_{f}$ karheusvaikutus, $\Delta C_{a}$ mittakaavakerroin, $\Delta C_{b l}$ bulbin vaikutus ja $\Delta C_{l}$ akselirakenteista ja ohjailusta muodostuva vastuslisä. Yhtälö ei sisällä aluksen painuman (squat) vaikutusta, mikä erityisesti matalassa vedessä operoitaessa voi muodostaa huomioitavan suuruisen lisävastuksen. Aluksen ollessa kulussa sen syväyteen ja vallitsevaan nopeuteen nähden riittävän syvässä vedessä tämä vaikutus kuitenkin heikkenee merkittävästi $[45,46]$. Asiaa voidaan tarkastella Frouden syvyysluvulla

$$
F n_{h}=\frac{v_{\text {nop }}}{\sqrt{g h_{\text {vesi }}}}
$$

missä $v_{\text {nop }}$ on aluksen nopeus $(\mathrm{m} / \mathrm{s}), g$ painovoimakiihtyvyys $\left(\mathrm{m} / \mathrm{s}^{2}\right)$ ja $h_{\text {vesi }}$ veden syvyys $(\mathrm{m})$. Frouden syvyysluvun avulla voidaan tehdä johtopäätöksiä aluksen muodostaman aaltosysteemin dynamiikasta. Syvyysluvun ollessa alle 0,55 [47], muistuttaa aaltosysteemi ominaisuuksiltaan Kelvin-aallokkoa, vaikkakin todellinen aaltokuvio onkin klassista Kelvinin aaltoteoriaa monimutkaisempi ja sisältää erityisesti tämän kokoluokan aluksilla myös Bernoullin aaltoja [45]. 
Kuitenkin Frouden syvyysluvusta voidaan tehdä johtopäätös, että merenpohjaefekti voidaan kohtuullisella tarkkuudella jättää huomioimatta tarkastelemalla aluksen kulkua operointinopeuksilla 20-25 solmua (n. 10-13 m/s) vain sellaisilla merialueilla, joissa veden syvyys on 40-50 metriä tai enemmän (kuva 1). Tämä on havaittavissa myös käytännössä aluksella, jolta tässä tutkimuksessa käsitelty data on tallennettu: Erityisesti veden syvyyden alittaessa 20 metriä aluksen nopeus hidastuu ilman tehon lisäämistä ja rungon värähtelyiden kasvaminen on havaittavissa empiirisesti.

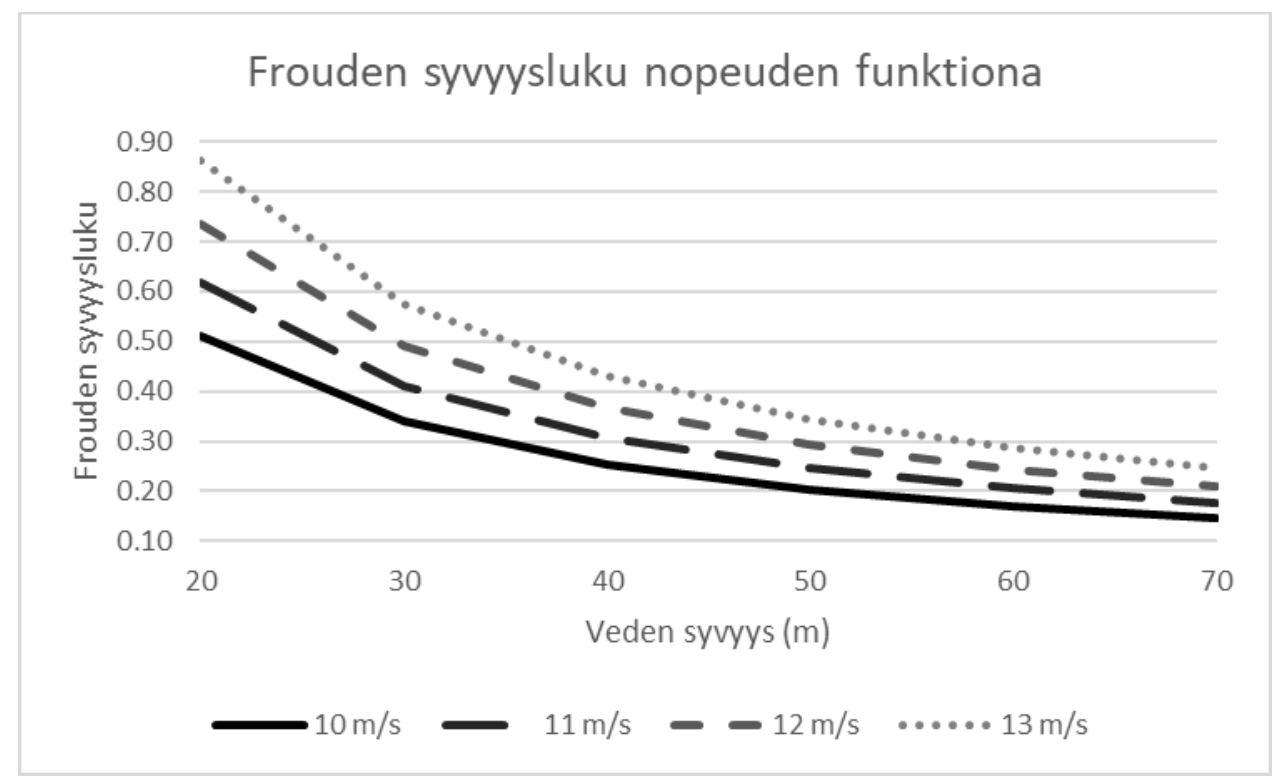

Kuva 1. Frouden syvyysluku nopeuden funktiona

Aluksen potkuriakseleiden, keulapotkuritunneleiden ja vakaajien muodostama vastuslisä joudutaan arvioimaan. Evävakaajia lukuun ottamatta näiden rakenteiden muodostaman vastuksen voidaan olettaa muuttuvan lineaarisesti nopeuden funktiona. Operoitaessa hyvässä säässä vakaajia ei käytetä. Ohjailutarpeeseen ja sen tuottamaan vastuslisään vaikuttaa merkittävästi operoitava väyläosuus ja sää. Avomerilegeillä tuulesta tai virtauksesta aiheutuvan mahdollisen sorron kompensointi on yleensä merkittävin ohjailuvastusta lisäävä tekijä. Säätilan vaihtelusta muodostuvia lisävastuskomponentteja voidaan yhtälöön 8 tarpeen vaatiessa lisätä. Näitä ovat esimerkiksi aluksen trimmin muutokset ja aluksen liikkeet meren pinnan suhteen.

Frouden mukaan aluksen hydrodynaamiset vastuskomponentit voidaan jakaa kitkavastukseen ja jäännösvastukseen. Kitkavastuskerroin $C_{f}$ määritetään ITTC-57:n perustella [40] yhtälöllä

$$
10^{3} C_{f(I T T C-57)}=\frac{0,075}{\left(\lg R_{n}-2\right)^{2}},
$$

missä $R_{n}$ on aluksen Reynoldsin luku. Se määritetään yhtälöllä

$$
R_{n}=\frac{v_{n o p} L_{w l}}{v_{\text {kin }}}
$$


missä $v_{n o p}$ on aluksen nopeus $(\mathrm{m} / \mathrm{s}), L_{w l}$ vesilinjan pituus $(\mathrm{m})$ ja $v_{k i n}$ veden kinemaattinen viskositeetti $\left(\mathrm{m}^{2} / \mathrm{s}\right)$. Kinemaattinen viskositeetti riippuu veden tiheydestä ja lämpötilasta, jonka approksimointi [36] voidaan tehdä yhtälöllä

$$
v_{\text {kin }}=\left(\left(43,4233-31,38 \rho_{\text {vesi }}\right)(t+20)^{1,72 \rho_{\text {vesi }}-2,202}+4,7478-5,779 \rho_{\text {vesi }}\right) 10^{-6},
$$

missä $t$ on veden lämpötila $\left({ }^{0} \mathrm{C}\right)$ ja $\rho_{\text {vesi }}$ tiheys $\left(\mathrm{kg} / \mathrm{m}^{3}\right)$. ITTC-78 on täydentänyt ITTC-57:n esittämää kitkavastusyhtälöä Granvillen $[10,36,38]$ muotokertoimella $k$ :

$$
10^{3} C_{f(I T T C-78)}=(1+k) \frac{0,075}{\left(\lg R_{n}-2\right)^{2}},
$$

määrittäen samalla yhtälön kuvaavan kitkavastuksen sijaan pikemminkin veden viskoottista vastusta. Granvillen muotokertoimen alkuperäinen muoto sisälsi muuttujina ainoastaan uppouman täyteläisyysluvun, aluksen pituuden ja leveyden. Kertoimesta on sittemmin luotu useita versioita [48, 49] huomioimaan paremmin erityyppiset tutkimuskohteet. Tässä tutkimuksessa on käytetty muotoa, mikä huomioi paremmin lastauksen seurauksena tapahtuneet syväyden muutokset:

$$
k=-0,030+\frac{32,8 C_{b}^{2}}{\left(\frac{L_{O S}}{B}\right)^{2}\left(\frac{B}{T}\right)}
$$

Vaihtoehtoinen menetelmä kitka- tai viskoottisen vastuksen määrittämiseen on soveltaa Grigsonin yhtälöä. [10, 41, 42] Tämä yhtälö määrittää viskoottisen vastuksen Reynoldsin luvun funktiona ja on havaittu suhteellisen tarkaksi, mutta jota ei ole kuitenkaan liitetty ITTC-standardeihin. Yhtälöstä on johdettu kaksi versiota riippuen Reynoldsin luvun suuruusluokasta:

$$
\begin{gathered}
10^{3} C_{f(\text { Grigson })}=\left(0,93+0,1377\left(\lg R_{n}-6,3\right)^{2}-0,06334\left(\lg R_{n}-6,3\right)^{4}\right) * \frac{0,075}{\left(\lg R_{n}-2\right)^{2}} \\
\operatorname{kun} 1,5 * 10^{6}<R_{n}<2 * 10^{7} \\
\text { tai } \\
10^{3} C_{f(\text { Grigson })}=\left(1,032+0,02816\left(\lg R_{n}-8\right)-0,006273\left(\lg R_{n}-8\right)^{2}\right) * \frac{0,075}{\left(\lg R_{n}-2\right)^{2}} \\
\operatorname{kun} 10^{8}<R_{n}<4 * 10^{9} .
\end{gathered}
$$

Jäännösvastuskomponentti muodostuu pääasiassa aluksen muodostaman aaltosysteemin aiheuttamasta kulkuvastuksesta. Taylorin-Gertlerin ja Harvaldin-Guldhammerin kertoimiin [43, 44] perustuva lauseke jäännös- eli aaltovastuksen mallintamiseen on muotoa:

$$
\begin{gathered}
10^{3} C_{r}=1,2 * 10^{-3}\left(10 * F_{n}-0,8\right)^{4}\left(10 * C_{p}-3,3\right)^{2}\left(10^{3} C_{v}+4\right)+0,05 * 10^{3} C_{v}+ \\
0,2+0,17\left(\frac{B}{T}-2,5\right),
\end{gathered}
$$

missä $F_{n}$ on Frouden luku 


$$
F_{n}=\frac{v_{n o p}}{\sqrt{g L_{o s}}}
$$

minkä termeistä $g$ on painovoimakiihtyvyys $\left(\mathrm{m} / \mathrm{s}^{2}\right)$, $v_{\text {nop }}$ aluksen nopeus $(\mathrm{m} / \mathrm{s})$ ja $L_{o s}$ hydrodynaaminen pituus $(\mathrm{m})$. Jäännösvastuslauseke esitetyillä kertoimilla pätee seuraavien ehtojen täyttyessä:

$$
\begin{gathered}
0,17<F_{n}<0,30 \\
2<10^{3} C_{V}<11 \\
0,5<C_{p}<0,8 \\
C_{b}<1,08-1,68 F_{n}+0,06
\end{gathered}
$$

Esitetty jäännösvastuslauseke vaatii bulbirakenteen aaltovastusta vähentävän vaikutuksen huomioimisen erillisellä yhtälöllä. Parhaimmillaan bulbirakenne vähentää aluksen aaltovastusta huomattavasti edellyttäen kuitenkin, että operointinopeus ja keulan trimmi ovat bulbiin nähden optimaalisia [50, 51]. Mikäli nämä aluskohtaiset ehdot toteutuvat, voidaan bulbirakenteen vastusta vähentävää vaikutusta arvioida yksi- tai kaksipotkurisella RORO/ROPAX-aluksella yhtälöllä [36, 37]:

$$
10^{3} \Delta C_{b l}=-0,2-1,1 * F_{n},
$$

tai kaksoisskeg-perärakenteella varustetulla, kaksipotkurisella aluksella yhtälöllä:

$$
10^{3} \Delta C_{b l}=0,52-2,6 * F_{n} .
$$

Pohjan likaantumisen seurauksena aluksen viskoottinen vastus kasvaa. Pienillä operointinopeuksilla viskoottisen vastuksen suhteellinen osuus on suurimmillaan, jolloin muutokset siinä lisäävät merkittävästi aluksen kokonaisvastusta. Laivapolttoaineiden vuodesta 2008 tapahtuneiden hintojen heilahtelujen seurauksena monet varustamot ovat aikatauluttaneet aluksensa hitaammille nopeuksille, jolloin viskoottisen vastuksen suhteellinen osuus kasvaa. ITTC-57:n hyväksymä kitkavastusyhtälö, sen Granvillen kertoimella toteutettu täydennys tai Grigsonin esittämä laskentamenetelmä eivät kuitenkaan sisällä pinnankarheutta mallintavaa komponenttia, minkä vuoksi pinnankarheudesta aiheutuva vastuslisä on esitettävä erillisenä kertoimena. Tämä analogia biologisen likaantumisen ja pinnankarheuden välillä ei ole ristiriidaton, sillä riippuen pohjan likaantumisasteesta ja pohjaan kiinnittyneiden kasvien, levien tai eliöstöjen lajeista ja -tyypeistä, voi havainnoitavissa oleva pinnankarheus vaihdella nopeuden funktiona veden painaessa kasvustoa tiiviimmin pohjaa vasten [52-54]. Nämä kaikki vaikuttavat virtausrajakerroksen muodostumiseen aluksen pohjan ympärille. Myös keinunta ja muut aluksen liikkeet voivat vaikuttaa merkittävästikin erityisesti suurempien kasvustojen aiheuttamaan vastuslisään.

Biologisesta aineksesta likaantuneen pohjan pinnankarheuden mittaaminen ja määrittäminen on siis käytännössä huomattavasti haastavampaa ja moniselitteisempää verrattuna esimerkiksi pintakäsitellyn teräslevyn pinnankarheuden määrittämiseen $[55,56]$. Lisäksi kasvustoilla ja levillä on taipumus kasvaa voimakkaimmin vesirajassa ja sen välittömässä läheisyydessä. Alusten pohjien satamissa tehtävät puhdistukset yleensä painottuvatkin rungon näille alueille. Merialueesta jonkin verran riippuen Itämeren olosuhteissa alusten auringonvalolta suojassa oleva, aluksen tasapohja harvemmin kerää itseensä merkittävästi biologista ainesta. Sitä vastoin tavallista 
on, että alusten kyljet puhdistetaan käytetystä maalityypistä riippuen kesäkaudella muutaman viikon välein.

Mikäli aluksen pohjan voidaan olettaa likaisimmillaankin olevan suhteellisen puhdas, voidaan pinnankarheuden aiheuttamaa lisävastusta mallintaa yhtälöllä [53]:

$$
10^{3} \Delta C_{f}=0,044 *\left(\sqrt[3]{\frac{k_{s}}{L_{w l}}}-\frac{10}{\sqrt[3]{R_{n}}}\right)+0,000125
$$

missä $k_{s}$ on pohjan keskimääräinen pinnankarheus, $L_{w l}$ vesilinjan pituus ja $R_{n}$ Reynoldsin luku. Tämä yhtälö on alun perin johdettu mallintamaan märkäpinta-alan pintakäsittelylaadun vaikutusta aluksen kulkuvastuksiin, minkä vuoksi sen epätarkkuus kasvaa pinnankarheusarvon ylittäessä $250 \mu \mathrm{m}$. Erittäin likaisten pohjien mallintamiseen sitä ei siis pidä sellaisenaan käyttää, mutta pohjien pesuvälejä optimoitaessa tarkoitus ei olekaan antaa pohjan likaantua merkittävästi ennen puhdistuspäätöksen tekemistä. Koska pohjan likaantuminen on todellisuudessa epätasaista, on esitettyä yhtälöä käytettäessä pohjan arvioitu keskimääräinen pinnankarheusarvo laskettava painottaen eri osien likaantuneisuutta ja niiden osuutta aluksen rungon märkäpinta-alasta.

Mikäli aluksen pohjaan on kiinnittynyt merkittävästi kooltaan suurempaa eliöstöä, voidaan keskimääräistä pinnankarheutta approksimoida yhtälöllä [13, 24]

$$
k_{s}=0,059 * k_{t} * \sqrt{x}
$$

missä $k_{t}$ on suurimpien eliöiden arvioitu korkeus ja $x$ prosenttiosuus, minkä niiden arvellaan peittävän tarkasteltavasta pinta-alasta. Sovellettaessa pinnankarheusyhtälöä on sen rinnalla käytettävä korrelaatiokerrointa:

$$
10^{3} \Delta C_{a}=5,68-0,6 \log _{10} R_{n}
$$

Aluksen pohjan märkäpinta-ala riippuu alustyypistä ja sillä on merkittävä vaikutus karheudesta aiheutuvaan kulkuvastuksen kasvuun. Märkäpinta-ala ei kuitenkaan välttämättä ole varustamojen tiedossa huolimatta kausittaisista alusten pohjien kunnostustarpeista. Lisäksi sen suuruus vaihtelee aluksen lastauksen ja trimmin funktiona. Märkäpinta-alan arviointiin on käytettävissä useita laskennallisia menetelmiä. Kaksipotkurisen, akselivetoisen ROPAX-aluksen märkäpinta-alan arviointiin on johdettu yhtälö [36, 43]

$$
S_{\text {ropax }}=1,21 *\left(\frac{V}{T}+1,3 * L_{w l} * T\right)\left(1,2-0,34 * C_{b}\right),
$$

joka tarkentaa vastaavan tyyppiselle, RORO-alukselle johdettua yhtälöä

$$
S_{\text {roro }}=1,53\left(\frac{V}{T}+0,55 * L_{w l} * T\right),
$$

uppouman täyteläisyyden osalta. Yleismallisia, alustyypistä riippumattomia yhtälöitä ovat muun muassa ITTC-57:n hyväksymä [40] laskentamenetelmä

$$
S_{57}=2,65 \sqrt{V L_{o s}} \text {, }
$$


missä $V$ on aluksen uppouma ja $L_{o s}$ hydrodynaaminen pituus. Aluksen rungon muotoa paremmin huomioiva yhtälö on löydettävissä Lewisin tuotannosta [38]

$$
\begin{gathered}
S_{\text {lew }}=L_{w l}(2 T+B) \sqrt{C_{m}}\left(0,4530+0,4425 C_{b}-0,2862 C_{m}-0,003467 \frac{B}{T}+\right. \\
\left.0,3696\left(0,18+0,86 C_{p}\right)\right)+2,38 \frac{A_{b t}}{C_{b}}
\end{gathered}
$$

missä $A_{b t}$ on bulbin poikkileikkauksen pinta-ala. Mumfordin yhtälöä [36] on sovellettu myös paljon:

$$
\begin{gathered}
S_{\text {mum } 1}=1,025 * L_{p p} *\left(C_{B} B+1,7 * T\right), \\
S_{\text {mum } 2}=1,025 *\left(\frac{V}{T}+1,7 * L_{p p} T\right), \\
\text { jolloin } \\
S_{\text {mum } 1}=S_{\text {mum } 2 .} .
\end{gathered}
$$

Kristensenin [37] tuotannosta on löydettävissä useita, alustyyppikohtaisia märkäpinta-alan laskentamenetelmiä. Näitä ovat muun muassa bulkkialusten ja tankkerien pinta-alan laskentaan soveltuva yhtälö

$$
S_{b t}=0,99\left(\frac{V}{T}+1,9 * L_{w l} * T\right),
$$

yksipotkurisille konttialuksille soveltuva versio

$$
S_{\text {cont }}=0,995\left(\frac{V}{T}+1,9 * L_{w l} * T\right),
$$

kaksoisskeg-perällä varustetuille RORO-aluksille

$$
S_{\text {skeg }}=1,2\left(\frac{V}{T}+1,5 * L_{w l} * T\right),
$$

sekä lossityyppisille, läpiajettaville lautoille johdettu yhtälö

$$
S_{\text {ferry }}=1,11\left(\frac{V}{T}+1,7 * L_{w l} * T\right)
$$

Yllä esitetyin yhtälöin on mahdollista mallintaa useita eri tyyppisiä aluksia soveltaen sellaisia muuttujia ja lähtötietoja, jotka todennäköisesti ovat varustamojen tiedossa tai jotka viranomaiset tai muut asiaa tutkivat tahot voivat halutessaan suhteellisen helposti selvittää. Operoinnin aikaiset muuttujat, kuten sääolosuhteet, tuottavat kuitenkin vaikeasti mallinnettavissa olevia vastuskomponentteja. Lisäksi optimoinnin kannalta yksi oleellinen tekijä on aluksen pohjan likaantumisnopeus. Siihen vaikuttavat operoitava merialue, vuodenaika, meren lämpötila ja valoisuusaste, seisonta-ajat satamissa ja aluksen pohjan pintakäsittelymenetelmä. Näistä helpoiten on selvitettävissä pintakäsittelymenetelmä, mistä varustamoilla on tarvittavat dokumentit arkistoissaan.

Aluksella, jolta tässä tutkimuksessa käsitelty data on tallennettu, käytetään kuparipohjaisia, orgaanisesta tinasta vapaita itsekiillottuvia myrkkymaaleja ainoastaan merivesikaivoissa, joihin kertyvä kasvusto voisi pahimmillaan aiheuttaa teknisiä ongelmia ja jotka tarjoavat usein mekaaniselta kulutukselta suojaisen alustan eliöstölle. Aluksen vedenalaiset kyljet ja pohja on 
käsitelty jääolosuhteisiin soveltuvilla, epoksipohjaisilla kovapintamaaleilla, joita ei kuitenkaan luokitella varsinaisiksi anti-fouling-maaleiksi. Valitun käsittelymenetelmän seurauksena pelkästään Itämerellä operoivana aluksena kylkiin kertyy kesäkaudella muutamassa viikossa jonkin verran levää siinä missä auringonvalolta suojassa oleva tasapohja säilyy puhtaana. Potkurit pysyvät puhtaana jatkuvan liikennöinnin seurauksena. Kylkiin kertyvät epäpuhtaudet vähenevät syvemmällä, minkä vuoksi puhdistus tehdään tarpeen mukaan (loppukesästä noin neljän viikon välein) ulottuen tavallisesti 3-6 metrin syvyyteen. Kasvustoa kertyy loppukesästä noin kuukauden aikana siten, että lähelle vesirajaa runkoon voi olla kiinnittynyt noin $10 \mathrm{~cm}$ pituisia, yksittäisiä leväkasvustoja, joiden pituus lyhenee mentäessä syvemmälle. Lisäksi lähellä pintaa olevat runkorakenteet ovat kauttaaltaan limamaisen kasvuston peittämiä. Noin neljän viikon välein tehtävän puhdistuksen aikana kasvusto irtoaa suhteellisen helposti, mutta puhdistusvälin pidentyessä 6-8 viikkoon kasvusto on selkeästi tiukemmin kiinnittynyt rakenteisiin. Itämerelläkin eri alueilla operoivilla aluksilla on vastaavasta pintakäsittelymenetelmästä huolimatta erilaisia kokemuksia kasvuston kehittymisestä. On alueita, joissa myös auringonvalolta suojassa oleva pohjarakenne on puhdistettava ajoittain siihen kiinnittyneistä eliöistä.

Koska Itämerellä operoivien alusten pohjia puhdistetaan tavallisesti ajoittain tai viimeistään jäissä liikennöinti irrottaa kylkiin kertynyttä kasvustoa, ei optimointityökalun tarkastelun kohteena olevien alusten runkorakenteet todennäköisesti koskaan pääse likaantumaan täysin vapaasti. Tämä merkitsee, että työkalun on ennen kaikkea sovelluttava analysoimaan suhteellisen pieniä muutoksia alusten kulkuvastuksissa. Connin, Lackenbyn ja Walkerin tuotannossa esitetyn nyrkkisäännön mukaan [11] voidaan arvioida kulkuvastuksen kasvavan pohjan likaantumisen takia noin 0,125 prosenttiyksikköä vuorokautta kohti. Tämä nyrkkisääntö soveltuu lämpimiin vesiin, mutta sitä voidaan kesäkaudella käyttää varovaiseen arviointiin myös Itämerellä. Sitä ei myöskään voi soveltaa sellaisenaan hyvin likaisille pohjille. Tämän avulla voidaan kuitenkin arvioida kulkuvastuksen kasvavan 20 vuorokauden aikana noin 2,5\%. Vastaavasti 30 ja 40 vuorokauden aikana vastus kasvaisi 3,75 ja 5 prosenttia. Toisaalta soveltaen tässä artikkelissa esiteltyjä laskentamenetelmiä, voidaan laskennallista muutosta kulkuvastuksessa arvioida erilaisilla pinnankarheusarvoilla. Mikäli aluksen pohjan keskimääräinen pinnankarheus kasvaisi $125 \mu \mathrm{m}$ :stä $250 \mu \mathrm{m}$ :iin, kasvaisi aluksen kulkuvastus 18-25 solmun nopeusalueella 4,2-3,3 prosenttia soveltaen Grigsonin yhtälöä tai 4,3-3,4 prosenttia ITTC-78:n laskentamallilla. Merkittävää eroa menetelmillä tässä tapauksessa ei siis ole. Myöskään muutosta laskettaessa eri pohjan märkäpintaalayhtälöitä soveltamalla tulokset poikkeavat vain prosentin kymmenesosan toisistaan.

Optimointityökalun soveltamista ajatellen tämä on tärkeä asia. On selvää, että kulkuvastuksen laskenta esitetyllä menetelmällä ja varustamoiden tai viranomaisten käytettävissä olevilla lähtötiedoilla sisältää epätarkkuutta. Mikäli epätarkkuus siirtyy kuitenkin lineaarisesti tuloksiin laskettaessa kulkuvastusta puhtaalla tai likaisella pohjalla, voidaan havaitusta eroavuudesta tehdä päätelmiä kulkuvastuksen muutoksesta. Sama pätee myös aluksen pohjan märkäpinta-alan arviointiin.

Pohjankarheuden vaikutusta aluksen kulkuvastukseen mallintava yhtälö 21 on kehitetty alun perin pintakäsittelyn jälkeisen pohjan sileysasteen vaikutusten arviointiin ja sen epätarkkuus kasvaa pinnankarheusarvojen noustessa yli $250 \mu \mathrm{m}$ [52]. Tavallisesti alusten puhtaiden pohjien pinnankarheus vaihtelee $100-150 \mu \mathrm{m}$ riippuen tavoitellusta pintakäsittelyn tasosta ja käytetystä pintakäsittelymenetelmästä. Mekaanisen kulumisen ja jäätalvien vaikutus on kaksijakoinen: Toisaalta kuluminen voi irrottaa maalista paloja lisäten näin karheutta, toisaalta etenkin sohjoisissa jääränneissä operoinnilla on taipumus hioa maalipintaa sileämmäksi. Mikäli pohjaan 
kertyvän kasvuston ajatellaan lisäävän pinnankarheutta ja kasvusto kertyy pääasiassa lähelle vesirajaa, on yhtälöä 21 sovellettava käyttämällä pinnankarheusarvona keskimääräistä pohjan pinnankarheutta. Mikäli siis noin 3 metrin syvyyteen ulottuvan osuuden kyljistä arvioitaisiin olevan pinnankarheudeltaan keskimäärin $600 \mu \mathrm{m}$ verrattavan leväkerroksen peitossa, mikä vastaisi noin $20 \%$ aluksen märkäpinta-alasta, olisi märkäpinnan keskimääräinen pinnankarheus 230-240 $\mu \mathrm{m}$, jolloin yhtälö 21 olisi periaatteessa edelleen sovellettavissa. Olettaen pohjan muiden alueiden vastaavan karheudeltaan $150 \mu \mathrm{m}$ pintaa, DWT:n ollessa $9653 \mathrm{t}$ ja syväyden 7,1 m, pohjan likaantumisesta aiheutuva teoreettinen kulkuvastuksen kasvaminen nopeusalueella 22-23 solmua on havainnollistettu kuvissa 2 ja 3. Kuvassa 2 laskenta on toteutettu Grigsonin yhtälöä soveltaen, kuvassa 3 ITTC-78 -menetelmällä.

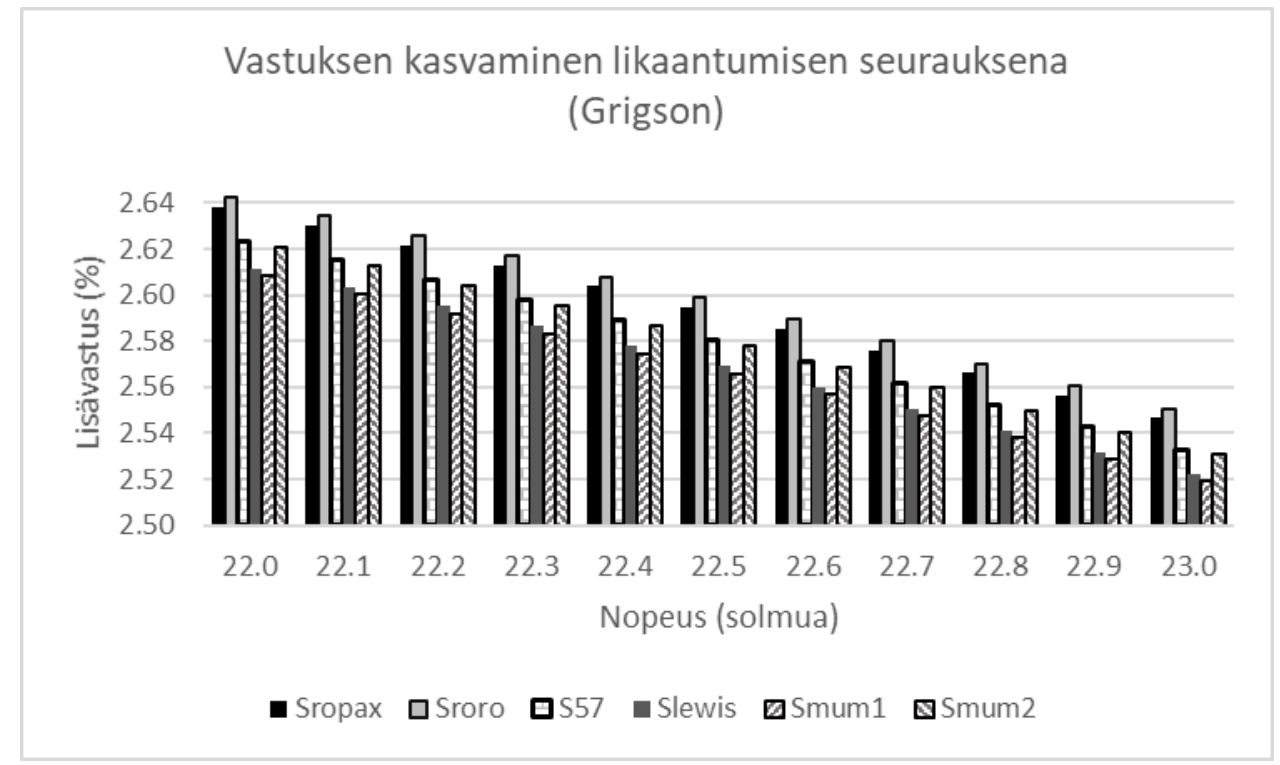

Kuva 2. Pohjan likaantumisesta seuraava vastuslisä nopeuden funktiona (Grigson)

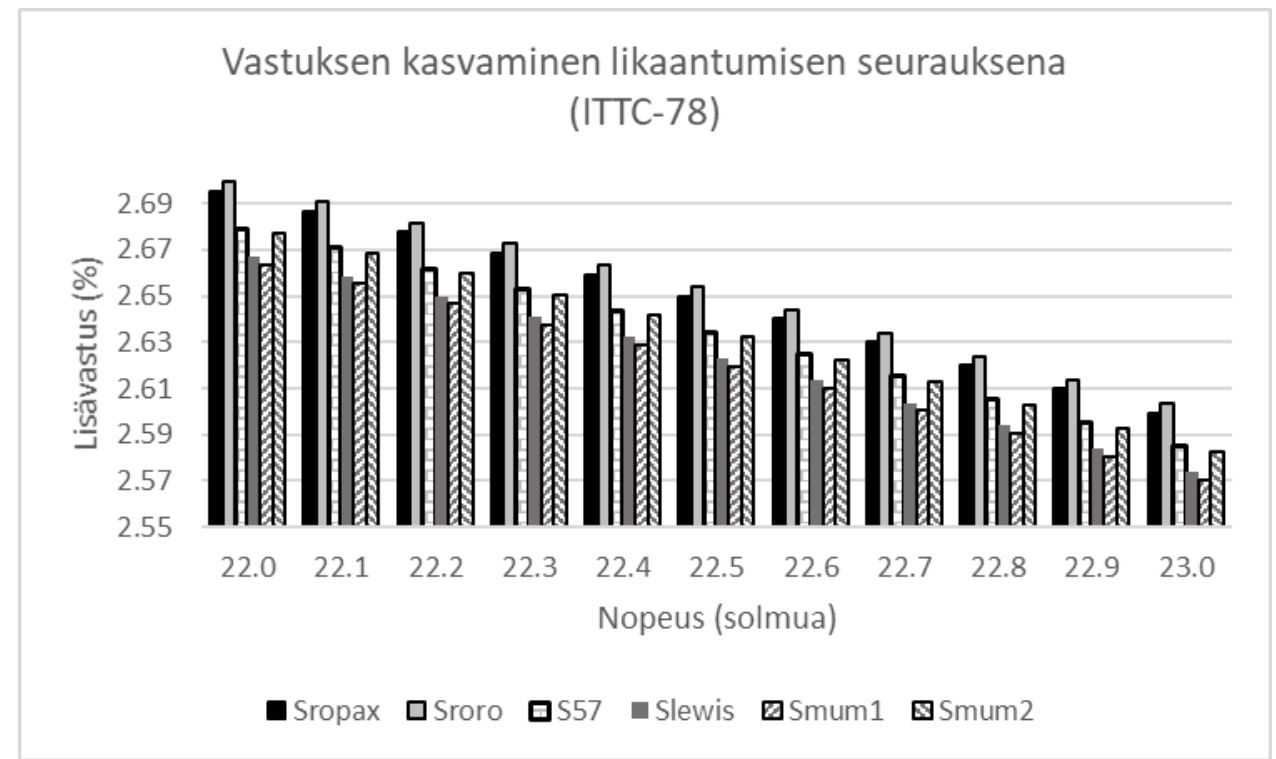

Kuva 3. Pohjan likaantumisesta seuraava vastuslisä nopeuden funktiona (ITTC-78) 
Mikäli kyseessä olisi alus, jonka pohja olisi hyvin likaantunut tai runkoon olisi kiinnittynyt suhteellisen isokokoisia eliöitä, yksi vaihtoehto olisi käyttää Schulzin johtamaa yhtälöä 22 tai vaihtoehtoisesti Oliveiran [52] tuotannossa esitettyä rajakerrokseen perustuvaa laskentamenetelmää. Pohjan karheuden, kuten monen muunkin fysikaalisen tekijän osalta, onnistuu teoreettisen viitekehyksen täydentäminen tarpeen vaatiessa.

\section{Tulosten vertailu empiirisiin havaintoihin}

Teoreettisen viitekehyksen antamia tuloksia verrataan normaalissa kulussa olevalta alukselta tallennettuun operointidataan. Dataa on tallennettu ajanjaksolla 20. heinäkuuta...3. syyskuuta 2018, mutta tutkimuksen tässä vaiheessa on oleellista selvittää datan ja laskentamallin yhteensopivuus ja havainnoida operointiolosuhteiden vaikutusta aluksen kulkuun. Data on tallennettu Itämerellä liikennöivältä, kaksipotkuriselta, akselivetoiselta, rakenteellisesti nopealta ROPAXalukselta.

Taulukko 2. Aluksen perussuureet

\begin{tabular}{lll}
\hline Tekijä & Symboli & Mitta \\
\hline Vesilinjan pituus & $\mathrm{L}_{\mathrm{wl}}$ & $211 \mathrm{~m}$ \\
Hydrodynaaminen pituus & $\mathrm{L}_{\mathrm{os}}$ & $218,8 \mathrm{~m}$ \\
Perpendikkelipituus & $\mathrm{L}_{\mathrm{pp}}$ & $199 \mathrm{~m}$ \\
Leveys & $\mathrm{B}$ & $30,5 \mathrm{~m}$ \\
Syväys & $\mathrm{T}$ & $7,1 \mathrm{~m}$ (max.) \\
Korkeus & $\mathrm{H}$ & $42 \mathrm{~m}$ \\
Runkopaino & $\mathrm{W}_{\text {alus }}$ & $17806 \mathrm{t}$ \\
Omapaino & $\mathrm{DWT}$ & $9653 \mathrm{t}$ (max.) \\
Keskilaivankaaren ala & $\mathrm{A}$ & $210 \mathrm{~m}^{2}$ \\
Uppouman täyteläisyys & $\mathrm{C}_{\mathrm{b}}$ & 0,5674 \\
Keskilaivankaaren täyteläisyys & $\mathrm{C}_{\mathrm{m}}$ & 0,9698 \\
Prismaattinen täyteläisyys & $\mathrm{C}_{\mathrm{p}}$ & 0,5851 \\
Uppouman hoikkuusluku & $\mathrm{C}_{\mathrm{v}}$ & 0,002567 \\
\hline
\end{tabular}

Taulukossa 2 esitetyt täyteläisyysluvut, keskilaivankaaren ala ja hoikkuusluku on laskettu suurimmalla sallitulla DWT:1lä. Näistä luvuista voidaan päätellä, että alus on rakenteellisesti nopea ja täyttää jäännösvastuslausekkeelle asetetut sovellettavuusehdot yli 15 solmun operointinopeuksilla. Nykyisellä linjallaan operointi on aikataulutettu siten, että aluksen matkanopeus asettuu pääsääntöisesti 21-23 solmun välille. Aluksessa on kaksi Promas Lite Rolls Royce KaMeWa CPP-potkuria halkaisijaltaan 4,8 metriä. Potkurin akseleiden pyörimisnopeudet ovat matkavauhdissa $150 \mathrm{rpm}$. Molempia akseleita pyörittää kaksi Wärtsilä 9L46D-moottoria, joiden konekohtainen maksimiteho on $10395 \mathrm{~kW}$. Nykyisellä reitillään kaikkia moottoreita 
ajetaan normaalisti 60-70 prosentin kuormalla. Molempiin akseleihin on kytketty $1100 \mathrm{~kW}$ akseligeneraattorit. Aluksessa on kaksi peräsintä, kaksi keulapotkuria ja molemmilla kyljillään sisään käännettävät evävakaajat.

Tarkasteltaessa aluksen operointia pääosin yli 40 metriä syvässä vedessä, voidaan pohjaefektin vaikutus aluksen kulkuun jättää huomioimatta. Esitetyt yhtälöt eivät huomioi aluksen painumaa ja sen vaikutusta kulkuvastukseen, toisaalta valituilla avomerilegeillä aluksen vauhti ja siitä riippuva painuma ovat yleensä suhteellisen vakioita. Myöskään ohjailutoimenpiteitä ei hyvissä sääolosuhteissa juurikaan tarvita, joten ohjailuvaikutuksen voidaan olettaa olevan liki nollaa. Näillä perusteilla valitaan ohjailu- ja avointen akselirakenteiden osalta muodostuvan lisävastuksen olevan lähellä alkusuunnittelussa käytettyä vakioarvoa, eli $6 \%$.

$$
10^{3} \Delta C_{l}=0,06
$$

Esimerkkejä ajanjaksolla 20. heinäkuuta...3. syyskuuta 2018 aluksen lastauksesta, siitä seuraavasta uppoumasta, keskilaivankaaren laskennallisesta alasta, syväydestä, täyteläisyysluvuista ja märkäpinta-alasta (yhtälö 24) on esitetty taulukossa 3. Merivesi on ollut ajanjaksolla poikkeuksellisen lämmintä. Tässä taulukossa lämpötilana on oletettu olleen $20^{\circ} \mathrm{C}$, suolapitoisuuden $0,5 \%$ ja tiheyden $1002 \mathrm{~kg} / \mathrm{m}^{3}$. Aluksen trimmi on vaihdellut lastauksen päätyttyä välillä $-0,2 \ldots 0,2 \mathrm{~m}$, kulkutrimmin asettuessa välille $-0,6 \ldots-0,4 \mathrm{~m}$.

Taulukko 3. Suureiden muuttuminen eri lastaustilanteissa

\begin{tabular}{cccccccc}
\hline DWT $(\mathrm{t})$ & $\mathrm{V}\left(\mathrm{m}^{3}\right)$ & $\mathrm{A}\left(\mathrm{m}^{2}\right)$ & $\mathrm{T}(\mathrm{m})$ & $\mathrm{C}_{\mathrm{b}}$ & $\mathrm{C}_{\mathrm{m}}$ & $\mathrm{C}_{\mathrm{p}}$ & $\mathrm{S}_{\text {ropax }}\left(\mathrm{m}^{2}\right)$ \\
\hline 5302 & 23062 & 191 & 6,5 & 0,532 & 0,963 & 0,552 & 6574 \\
5929 & 23687 & 197 & 6,7 & 0,530 & 0,964 & 0,550 & 6631 \\
6510 & 24267 & 201 & 6,8 & 0,535 & 0,969 & 0,552 & 6695 \\
7036 & 24792 & 201 & 6,8 & 0,546 & 0,969 & 0,564 & 6763 \\
7278 & 25034 & 207 & 7,0 & 0,536 & 0,970 & 0,553 & 6769 \\
7406 & 25162 & 204 & 6,9 & 0,546 & 0,969 & 0,564 & 6798 \\
7539 & 25294 & 207 & 7,0 & 0,541 & 0,970 & 0,558 & 6802 \\
7772 & 25527 & 207 & 7,0 & 0,546 & 0,970 & 0,564 & 6831 \\
8072 & 25827 & 207 & 7,0 & 0,553 & 0,970 & 0,570 & 6869 \\
8591 & 26344 & 210 & 7,1 & 0,556 & 0,970 & 0,573 & 6921 \\
9264 & 27016 & 210 & 7,1 & 0,570 & 0,970 & 0,588 & 7003 \\
\hline
\end{tabular}

Taulukossa 4 on esitetty yhtälöissä 23-28 esitetyillä menetelmillä laskettujen märkäpinta-alojen suhteellinen ero ROPAX-alukselle tarkoitetulla kaavalla (24) laskettuihin arvoihin. ROPAXalukselle sovelletun yhtälön antamat tulokset ovat suhteellisen lähellä RORO-yhtälön antamia vastauksia. ROPAX-yhtälössä on kuitenkin huomioitu uppouman täyteläisyysluvun muutokset, mikä tekee tuloksista vähemmän herkän syväysdatan muutoksille. Mikään esitetyistä yhtälöistä ei huomioi trimmin muutoksia, tosin täyteläisyystermi approksimoi sitä. Molemmat versiot Mumfordin yhtälöistä, Lewinsin tuotannosta löytyvä yhtälö ja ITTC-57:n hyväksymä yhtälö antavat selkeästi pienemmät arviot märkäpinta-alalle. Näiden yhtälöiden kehittämisen aikaan alusten runkorakenteet olivat tavallisesti nykyisiä selkeästi hoikempia, jolloin myös märkäpinta-ala on pienempi. Mumfordin yhtälöiden tulosten pitäisi periaatteessa olla vertailukelpoisia, mitä ne eivät tällä alustyypillä selkeästi ole. 
Taulukko 4. Eri menetelmillä laskettujen märkäpinta-alojen suhteelliset erot verrattuna ROPAXalukselle tarkoitetun menetelmän antamiin arvoihin

\begin{tabular}{llllll}
\hline DWT $(\mathrm{t})$ & $\mathrm{S}_{57}(\%)$ & $\mathrm{S}_{\text {lew }}(\%)$ & $\mathrm{S}_{\mathrm{mum} 1}(\%)$ & $\mathrm{S}_{\mathrm{mum} 2}(\%)$ & $\mathrm{S}_{\text {roro }}(\%)$ \\
\hline 5302 & $-9,46$ & $-11,19$ & $-15,41$ & $-10,40$ & 0,12 \\
5929 & $-9,02$ & $-11,28$ & $-15,26$ & $-10,31$ & $-0,48$ \\
6510 & $-8,79$ & $-11,28$ & $-15,08$ & $-10,14$ & $-0,40$ \\
7036 & $-8,74$ & $-11,01$ & $-14,88$ & $-9,88$ & 0,33 \\
7278 & $-8,37$ & $-11,31$ & $-14,89$ & $-9,99$ & $-0,80$ \\
7406 & $-8,53$ & $-11,02$ & $-14,79$ & $-9,82$ & 0,10 \\
7539 & $-8,35$ & $-11,17$ & $-14,79$ & $-9,86$ & $-0,45$ \\
7772 & $-8,32$ & $-11,04$ & $-14,71$ & $-9,75$ & $-0,13$ \\
8072 & $-8,29$ & $-10,88$ & $-14,59$ & $-9,61$ & 0,27 \\
8591 & $-8,07$ & $-10,82$ & $-14,45$ & $-9,48$ & 0,24 \\
9264 & $-8,00$ & $-10,44$ & $-14,20$ & $-9,16$ & 1,13 \\
\hline
\end{tabular}

Sääolosuhteiden vaikutus minimoidaan tarkastelemalla legiä, jolloin tuuli- ja virtausolosuhteet ovat olleet mahdollisimman heikot. Tällaisella legillä alus on ollut 25.-26. heinäkuuta kello 20:00-14:00 (UTC). Tuolloin aluksen CNT-syväys on ollut 7,0 m ilmoitetun DWT:n ollessa 7772 tonnia. Aluksella on ollut suhteellisen vakiona pysynyt keulatrimmi $-0,4 \ldots-0,5 \mathrm{~m}$ potkureiden nousujen vaihdellessa akseleiden kuormitustilanteen mukaan lukualueella 85-90 \%. Aluksen nopeus- ja kurssi pohjan suhteen on esitetty kuvassa 4 HELCOM:n AIS-tallenteiden perusteella (tarkastelujaksolla 213 AIS-leimaa) ensimmäisen AIS-tallenteen aikaleiman ollessa 20:01 ja viimeisen 13:58 (UTC). Kurssissa on tehty ainoastaan pieniä muutoksia, jolloin sääolosuhteet huomioiden ohjailuvastus on todennäköisesti vähäinen. Pääosan legistä nopeus on myös varsin tasainen pysytellen 22-23 solmun välillä.

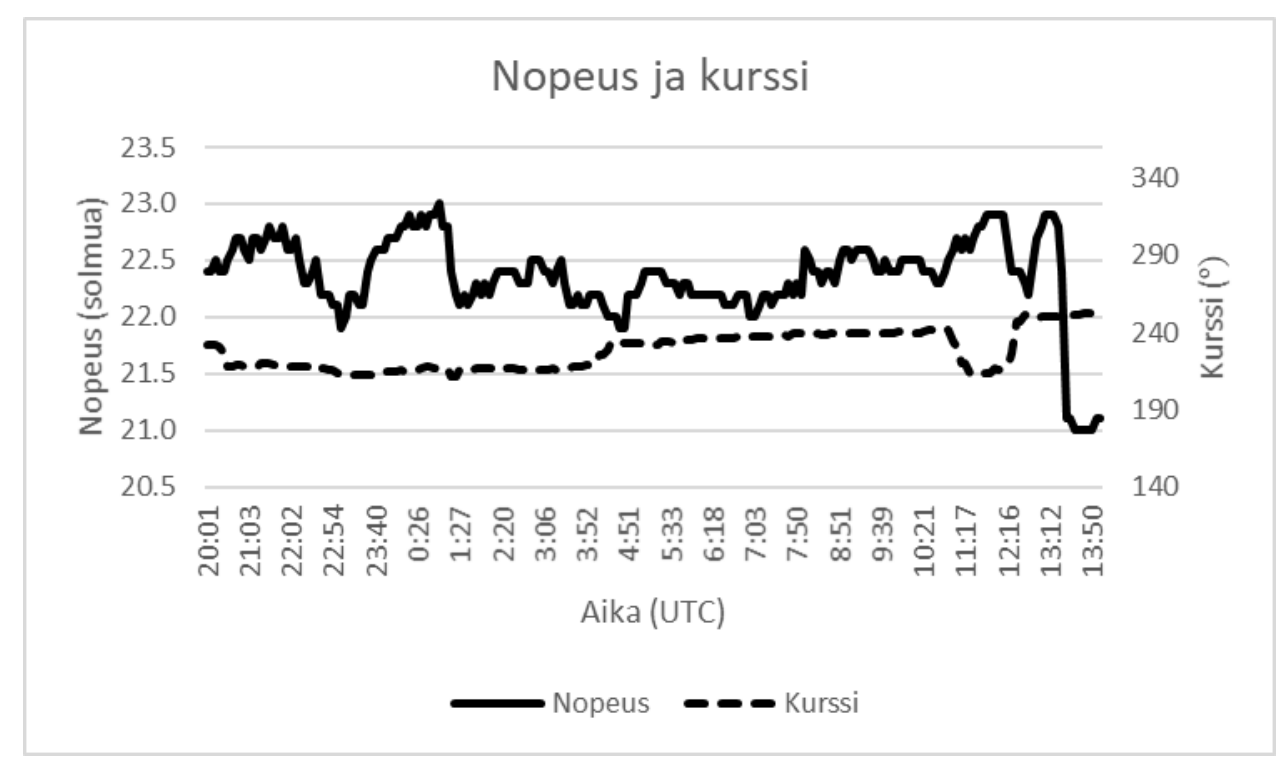

Kuva 4. Aluksen nopeus- ja kurssi

Aluksen akselitehossa tapahtuvat muutokset ovat nähtävissä kuvassa 5. Aikaikkuna on sama kuin kuvassa 4. Merkittävimmät muutokset legillä ovat tapahtuneet ensimmäisten tuntien aikana 
sekä ajanjakson lopussa. Nopeudessa havaittavat muutokset ovat vain osittain selitettävissä akselitehon muutoksilla. Osa muutoksista johtuu sää- ja virtausolosuhteista. Vaikka legillä sääolosuhteet ovatkin hyvät, jo muutaman metrin nopeudella puhaltava tuuli aiheuttaa tämän kokoisessa aluksessa merkittäviä muutoksia tuulivastukseen.

Laskettaessa alukselle teoreettinen kulkuvastus vallitsevalla nopeudella, matkakohtaisella lastidatalla ja jakamalla se akseleiden torsiometrien tuottamalla akselitehodatalla, saadaan teoreettinen hyötysuhdekäyrä, mikä on esitetty kuvassa 6 . Grigsonin kitkavastusyhtälön antamat tulokset ovat lineaarisesti 1-2 prosenttiyksikköä ITTC-78:n vastusyhtälöä suurempia, mutta muutoin täysin vertailukelpoisia keskenään. Vertaamalla laskennallista hyötysuhdetta aluksen lähettämään AIS-dataan sijaintitietoineen, saadaan käsitys operointiympäristössä vallitsevien olosuhteiden vaikutuksista aluksen kulkuun. Polttoaineen kulumisen vaikutus DWT:hen on matkakohtaisesti vähäinen (noin 1-1,5 prosentin muutos reitillä satamasta toiseen). Painolastivesimuutoksilla olisi selkeästi suurempi vaikutus, mikäli sellaisia jostain syystä tehtäisiin kesken legin. Kuten kuvasta 6 nähdään, paikoitellen nopeuden ja laskennallisen hyötysuhteen käyrissä tapahtuvat muutokset ovat vertailukelpoisia, mutta todennäköisesti sääolosuhteiden suhteellisen vähäisetkin muutokset ovat nähtävissä poikkeamina.

Potkureiden nousut ovat nähtävissä kuvassa 7. Nousukäyrät noudattavat varsin tarkasti akseleilta tallennetun tehodatan (kuva 5) muutoksia. Nousut ovat olleet jyrkimmillään akselitehon ollessa suurimmillaan ajanjaksoilla 23:30-01:00 ja 12:50-13:20 (UTC). Noin 04:25-04:50 näkyy sekä nopeus- että hyötysuhdekäyrässä (kuva 6) poikkeavuus, mitä tehodata (kuva 5) tai nousukäyrät (kuva 7) eivät selitä. Tuolloin alus vähän aiemmin kääntynyt uudelle legille (kuva 4) ja ohittanut Hoburgin matalan, jolloin pohjaefektillä ja alueella todennäköisesti ilmenevillä virtauksilla on todennäköisesti osuutensa tähän poikkeamaan. Lisäksi ajanjaksolla 23:20-01:30 näkyy teho- ja nousukäyrissä työntövoiman kasvu, joka on nostanut nopeutta viipeellä. Viipeen mahdollinen syy voi kuitenkin olla muuttuneissa sääolosuhteissa. Tallennusjakson lopussa 13:30 jälkeen tehoa on vähennetty (kuva 5), mikä näkyy myös nousujen alentumisena ja nopeuden vähenemisenä (kuva 7).

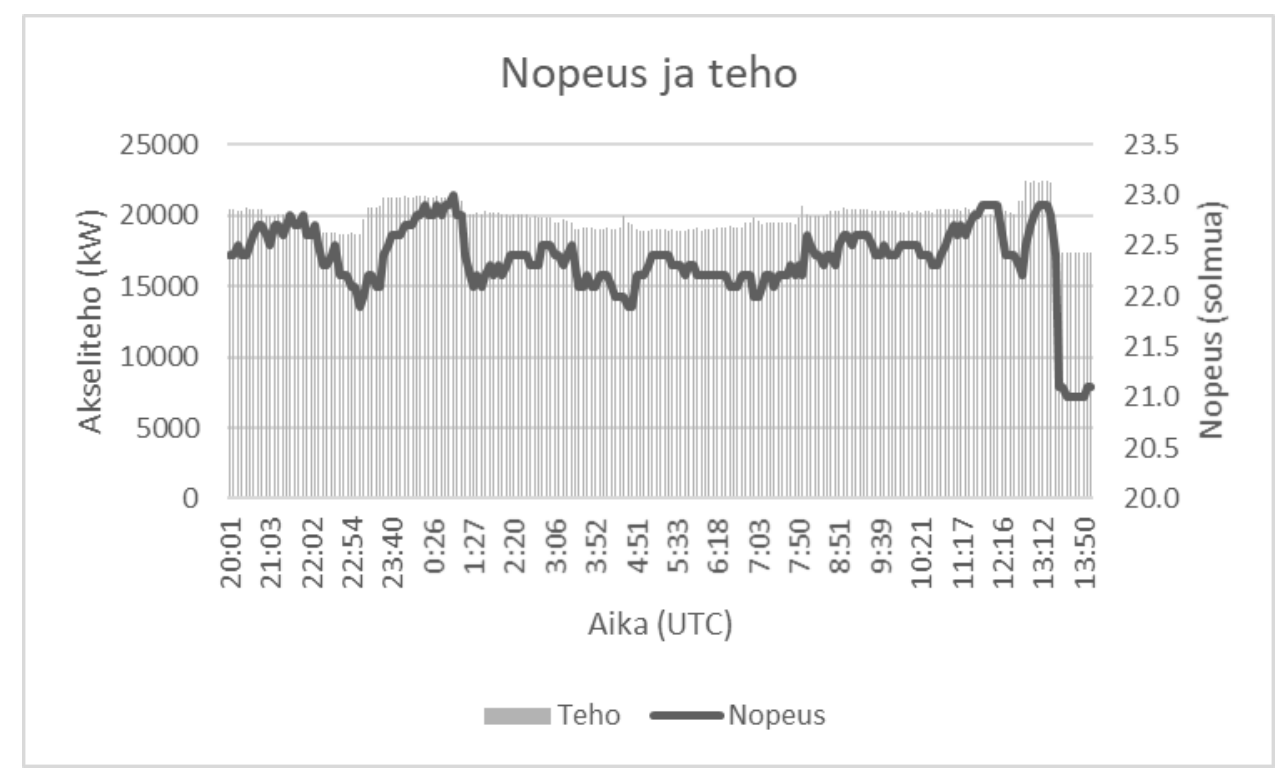

Kuva 5. Nopeus ja akseliteho 


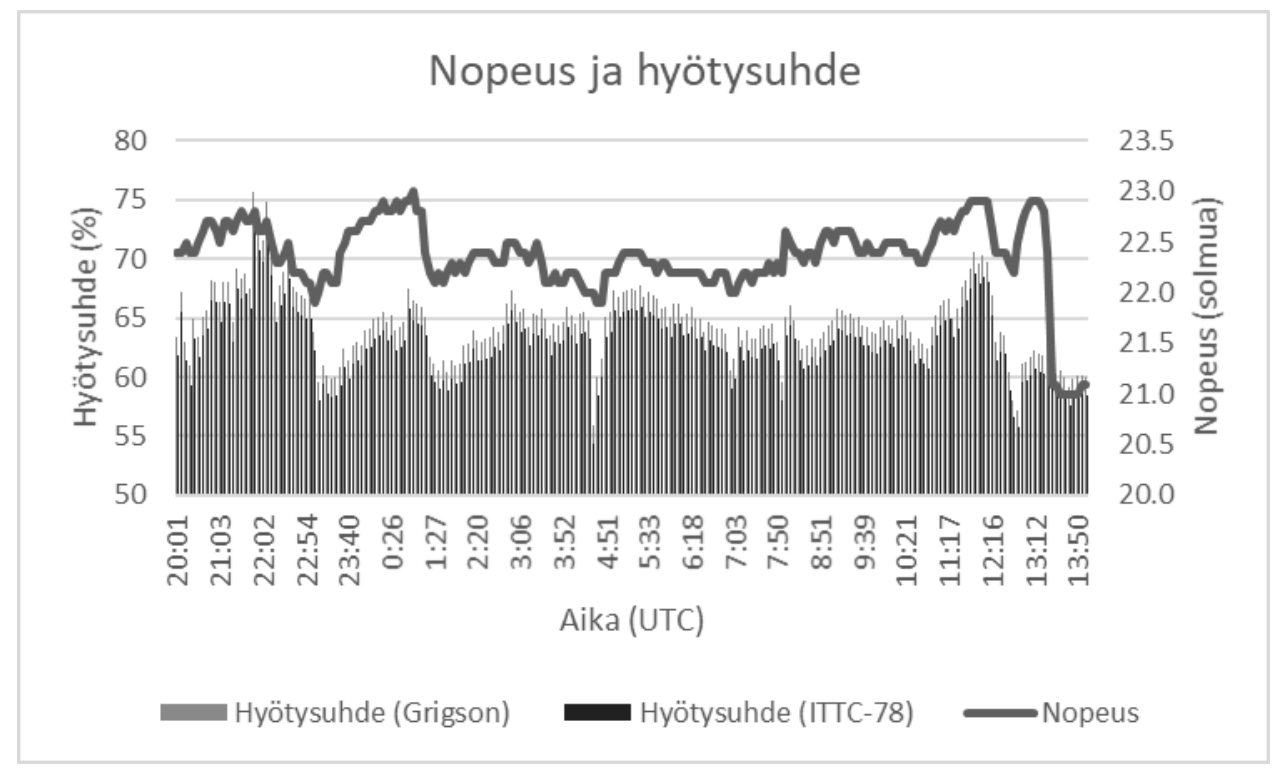

Kuva 6. Nopeus ja hyötysuhde

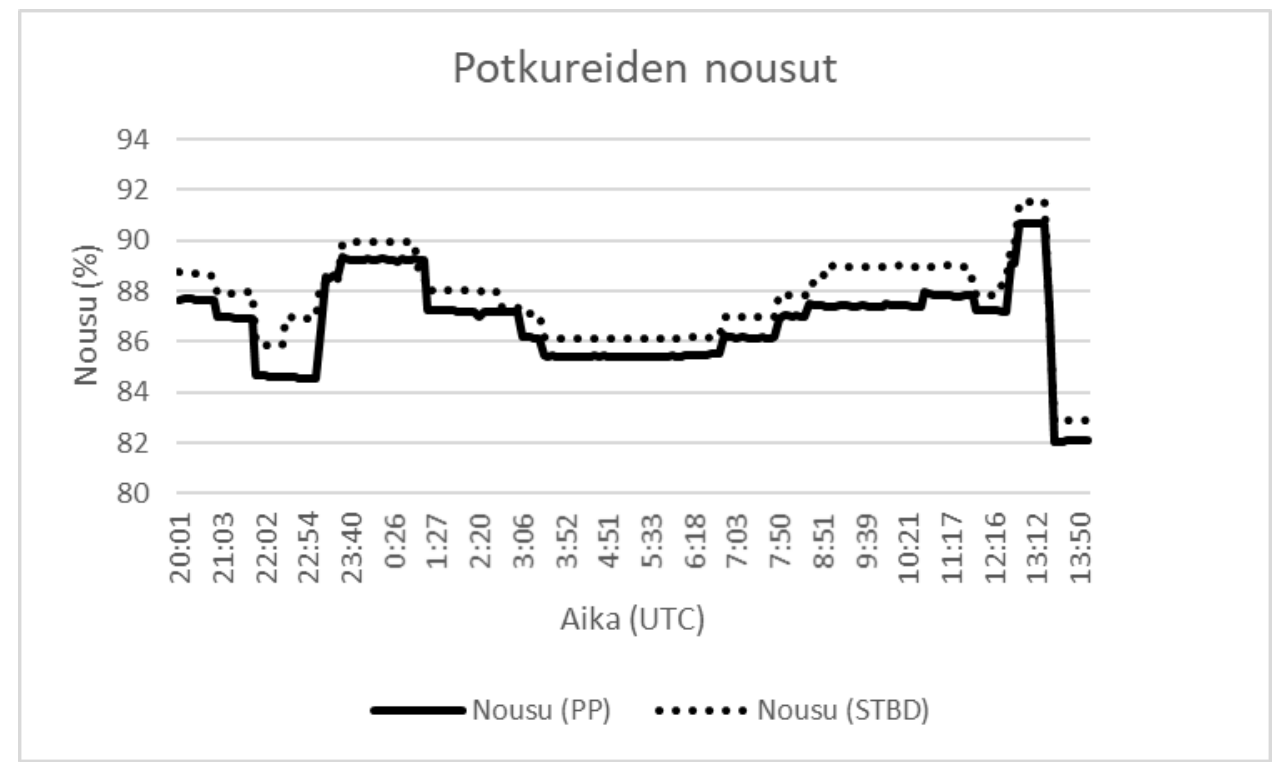

Kuva 7. Potkureiden nousut

Tarkastellaan aluksen operointidataa 25. heinäkuuta 22:00-00:00 (UTC), 30. heinäkuuta 21:00-23:00 (UTC) ja 31. heinäkuuta 22:00-00:00 (UTC), jolloin aluksen ilmoitettu DWT on ollut 7772 tonnia, 6510 tonnia ja 7864 tonnia. Alus on sijainnut kaikissa tapauksissa Gotlannin pohjoisella altaalla ja alueen rannikkoasemien tallentamat tuuliolosuhteet ovat olleet 1-2 boforia. BSH:n virtausennusteiden mukaan alueella ei ole ollut merkittäviä pintavirtauksia. Mittauslegien 
nopeudet ovat nähtävissä kuvassa 8, joka osoittaa aluksen kulkeneen kaikissa kolmessa tapauksessa normaalia matkanopeuttaan. X-akselilla on kumulatiivinen aikaleima kunkin tarkastelujakson alusta laskien.

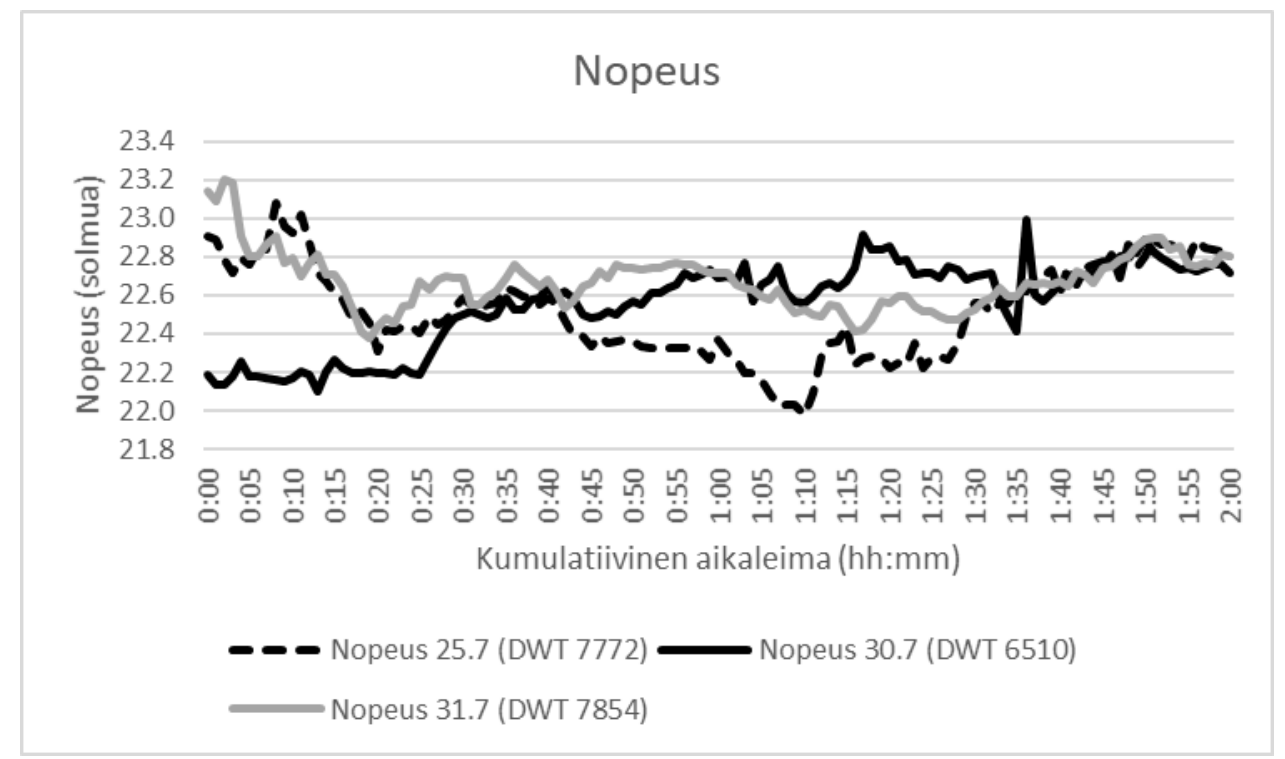

Kuva 8. Aluksen nopeus

Akseleiden tehokäyrät ovat nähtävissä kuvassa 9. Valituista ajanjaksoista ainoastaan 30. heinäkuuta akseliteho on pidetty lähes vakiona. Sekä 25. että 31. heinäkuuta luoduissa tallenteissa näkyvät selkeästi uudet konekäskyt, joiden todennäköisenä syynä on tavoitteena pitää matkanopeus suhteellisen vakiona tuulen voimistuessa. Vaikka rannikkoasemien mukaan tuuliolosuhteet ovatkin olleet mittauksia ajatellen suotuisat, voivat olosuhteet avomerellä poiketa rannikon olosuhteista. Toisaalta myös 30 . heinäkuuta vakiotehosta huolimatta aluksen nopeus on kasvanut selkeästi mittausjakson aikana, minkä todennäköisenä syynä ovat tuulen suunnan tai nopeuden muutokset. Erityisesti mittausjaksojen loppuvaiheessa (viimeiset 15 minuuttia) aluksen nopeudet ovat olleet sattumalta liki samat akselitehojen ollessa kuitenkin selkeästi toisistaan poikkeavat. Aluksen DWT:n erot selittävät tuulen lisäksi havaittuja eroja, mutta painotusten luotettava havaitseminen on näistä käyristä haastavaa. Aikaleimoilla 00:20-00:35 nopeudet ovat myös olleet hyvin lähellä toisiaan, mutta 25. heinäkuuta raskaammassa lastissa (DWT 7772 t) ollut alus on tuona jaksona saavuttanut hieman suuremman nopeuden selkeästi pienemmällä koneteholla verrattuna 30. heinäkuuta vallinneeseen tilanteeseen (DWT 6510 t). Vertailtaessa 25. ja 31. heinäkuuta tallentuneita arvoja, on tehoero vielä selkeämpi nopeuden ja lastauksen ollessa lähes identtiset. Akselitehon ja nopeuden suhde on nähtävissä kuvassa 10, mistä voidaan nähdä solmua kohti vaadittava teho, mikä selkiyttää kuvien 8 ja 9 sisältämän datan hahmottamista visuaalisesti.

Kuvassa 11 on esitetty laskennalliset hyötysuhteet näille kolmelle esimerkkitapaukselle. Käytännössä tässä lähestymistavassa sovellettu laskennallinen hyötysuhde sisältää useita hyötysuhdekomponentteja, kuten potkureiden hyötysuhteet, rungon hyötysuhteen tai vakaajien mahdollisen käytön, sekä tuulen, aallokon tai virtausten vaikutuksen. Tulosten absoluuttiseen tarkasteluun menetelmä ei ole riittävän kattava, mutta pohjan likaantumisen aiheuttamaa lisävastusta haettaessa oleellista on tunnistaa lähinnä relatiivinen eroavuus ajettaessa rungoltaan puhtaalla tai likaisella 
aluksella. Tämän lähestymistavan etuna on muun muassa lastitilanteen ja nopeuden muutosten parempi huomiointi verrattuna kulutuksen tai tehon raakadatan käsittelyyn.

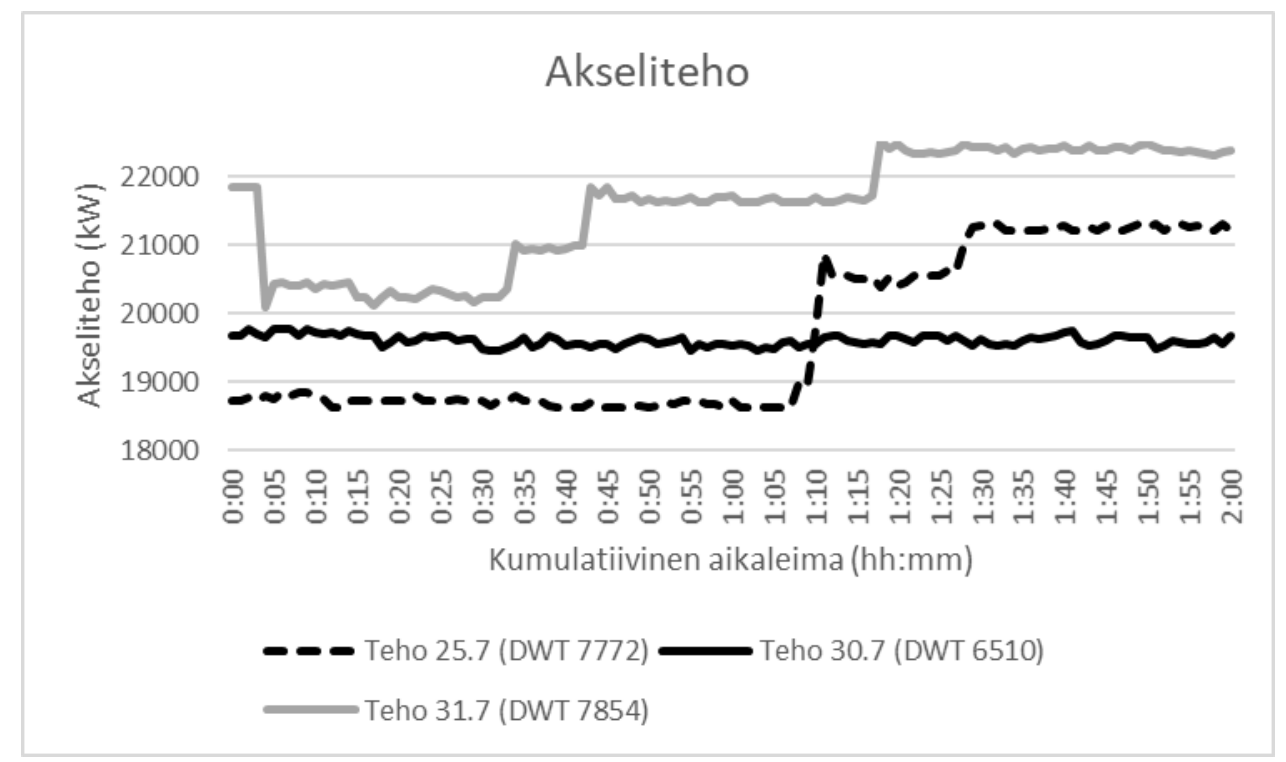

Kuva 9. Aluksen akseliteho

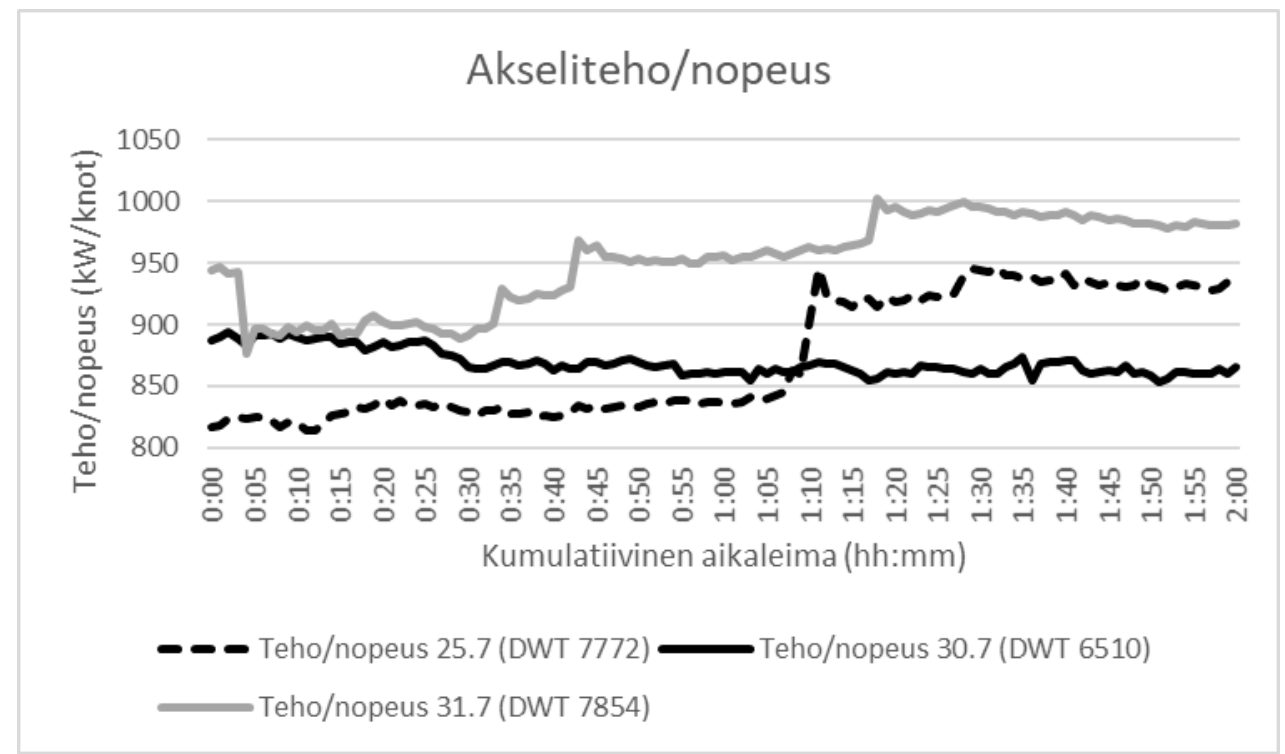

Kuva 10. Akselitehon suhde nopeuteen

Taulukossa 4 esitetään eroavuuksia, joita eri märkäpinta-alojen laskentamenetelmien käyttö antaa. Kuvassa 12 on nähtävissä hyötysuhdekäyrät, mitkä on laskettu alukselta 20:00-14:00 (UTC) minuutin välein tallentuneella datalla kuudella eri märkäpinta-alojen laskentamenetelmällä. Eroavuudet tulevat käyrästöstä selkeästi ilmi, mutta muutokset ovat keskenään hyvin lineaarisia. Lisäksi ROPAX- ja RORO-aluksille johdettujen märkäpinta-alayhtälöiden antamat tulokset eivät kuvassa esitetyllä tarkkuudella poikkea juurikaan toisistaan. 


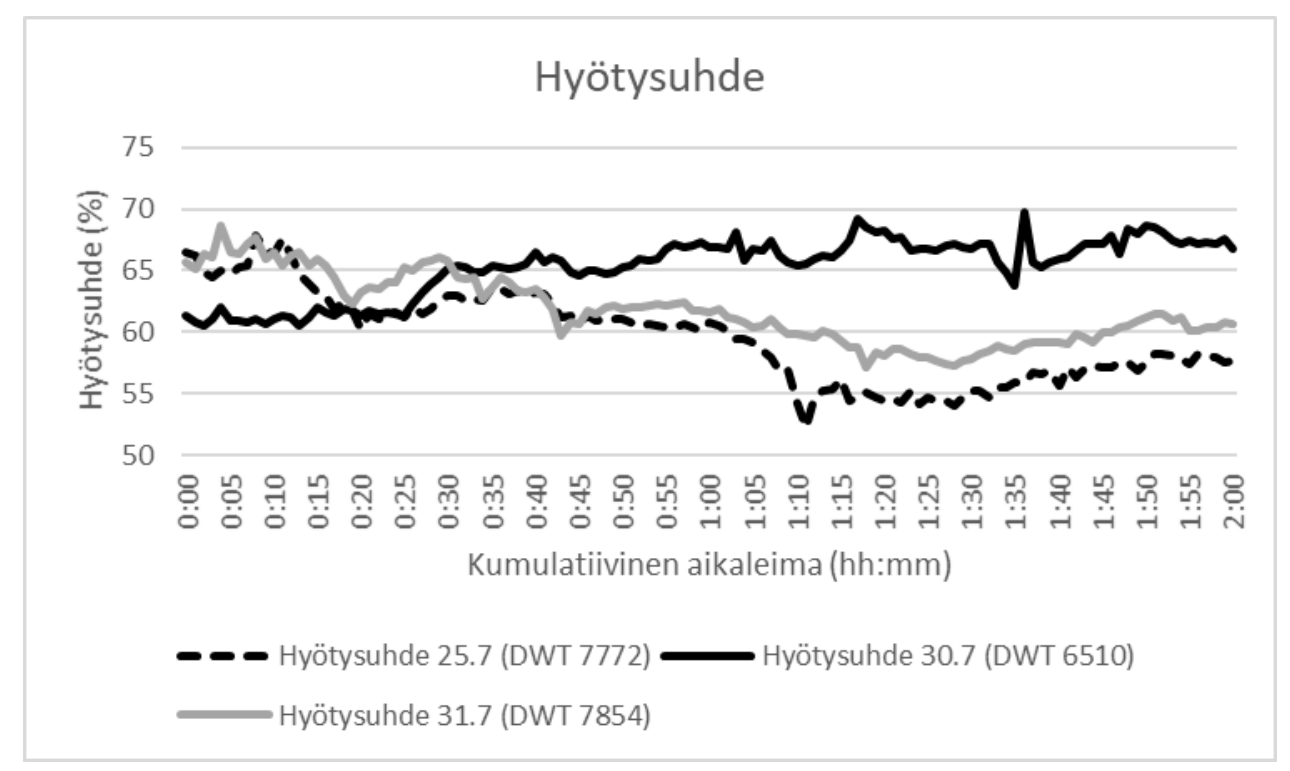

Kuva 11. Teoreettisen hyötysuhteen käyrät

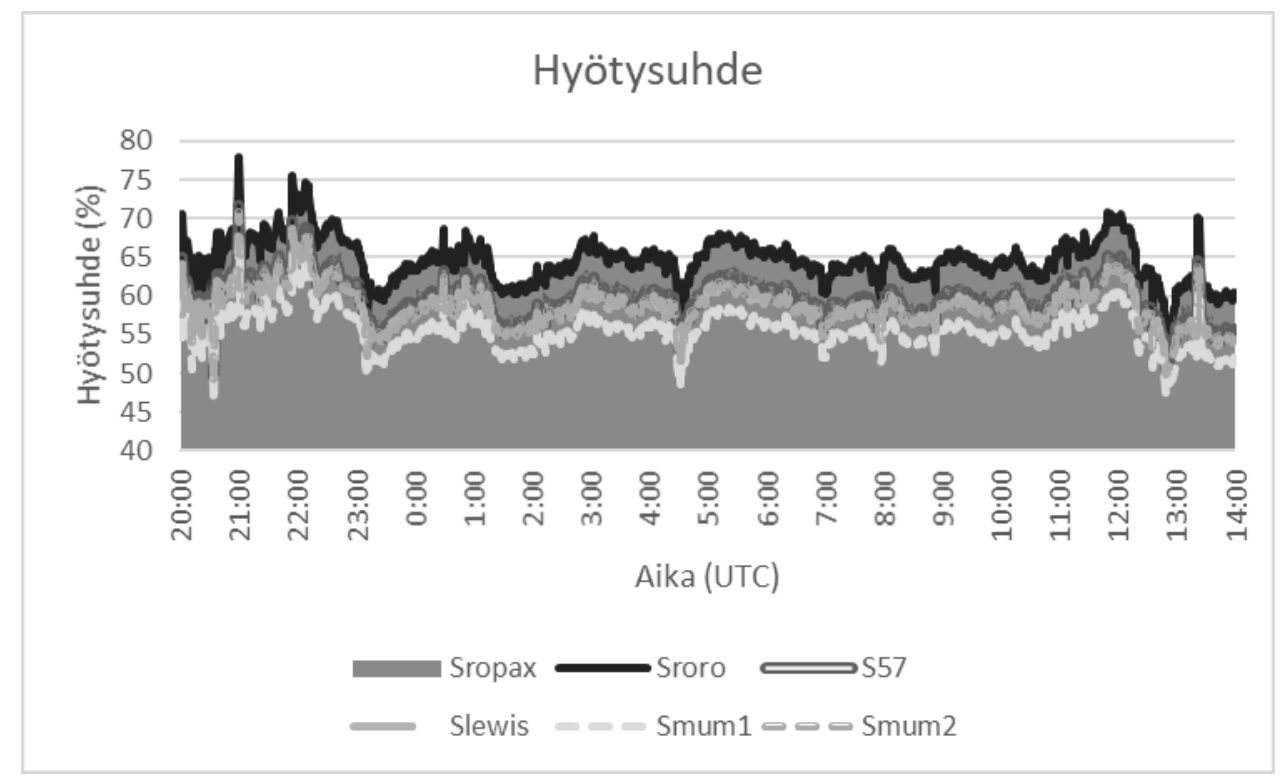

Kuva 12. Laskennallinen hyötysuhde eri pohjan märkäpinta-aloilla

\section{Virtaus-, aalto- ja tuuliolosuhteiden vaikutus}

Edellisessä luvussa on käsitelty aluksen kulkua hyvissä sääolosuhteissa ja verrattu alukselta otettujen tallenteiden dataa laskennallisiin arvoihin. Vaikka sääolosuhteet ovatkin hyvät, on jo vähäisilläkin operointiolosuhteiden muutoksilla havaittava vaikutus aluksen kulkuun. Hyödynnettäessä optimointityökalun kehitystyössä aluksilta tallennettua dataa on perusteltua käyttää vain sellaista dataa, mikä on tallentunut hyvissä sääolosuhteissa. Myös teoreettinen pohjan likaantumisen vaikutuksen arviointi aluksen kulkuvastukseen on perusteltua tehdä olettamalla sääolosuhteet 
ihanteellisiksi. Aluskohtaisesti on kuitenkin selvitettävä, millainen vaikutus sääolosuhteilla aluksen kulkuun on, jotta nämä "riittävän hyvät" sääolosuhteet voidaan tunnistaa. Käytännössä joka tapauksessa joudutaan tilastollisen ongelman eteen.

Dataan on tallentunut mielenkiintoinen vaihe 10. elokuuta 2018, jolloin alus kohtasi heikosta navakaksi tuuleksi voimistuneen tuulirintaman, jonka suunta aluksen suhteen oli vastainen. Samaan aikaan aluksen nopeus on pidetty suhteellisen vakiona moottoritehoja lisäämällä tuulen voimistuttua. Aluksen AIS:n antamat sijainti-, nopeus-, ja kurssileimat on visualisoitu kuvassa 13. Alus on tehnyt ainoan selkeän (noin 20 astetta) kurssimuutoksen kääntyessään Hoburgin kärjessä Bornholmin lanelle.

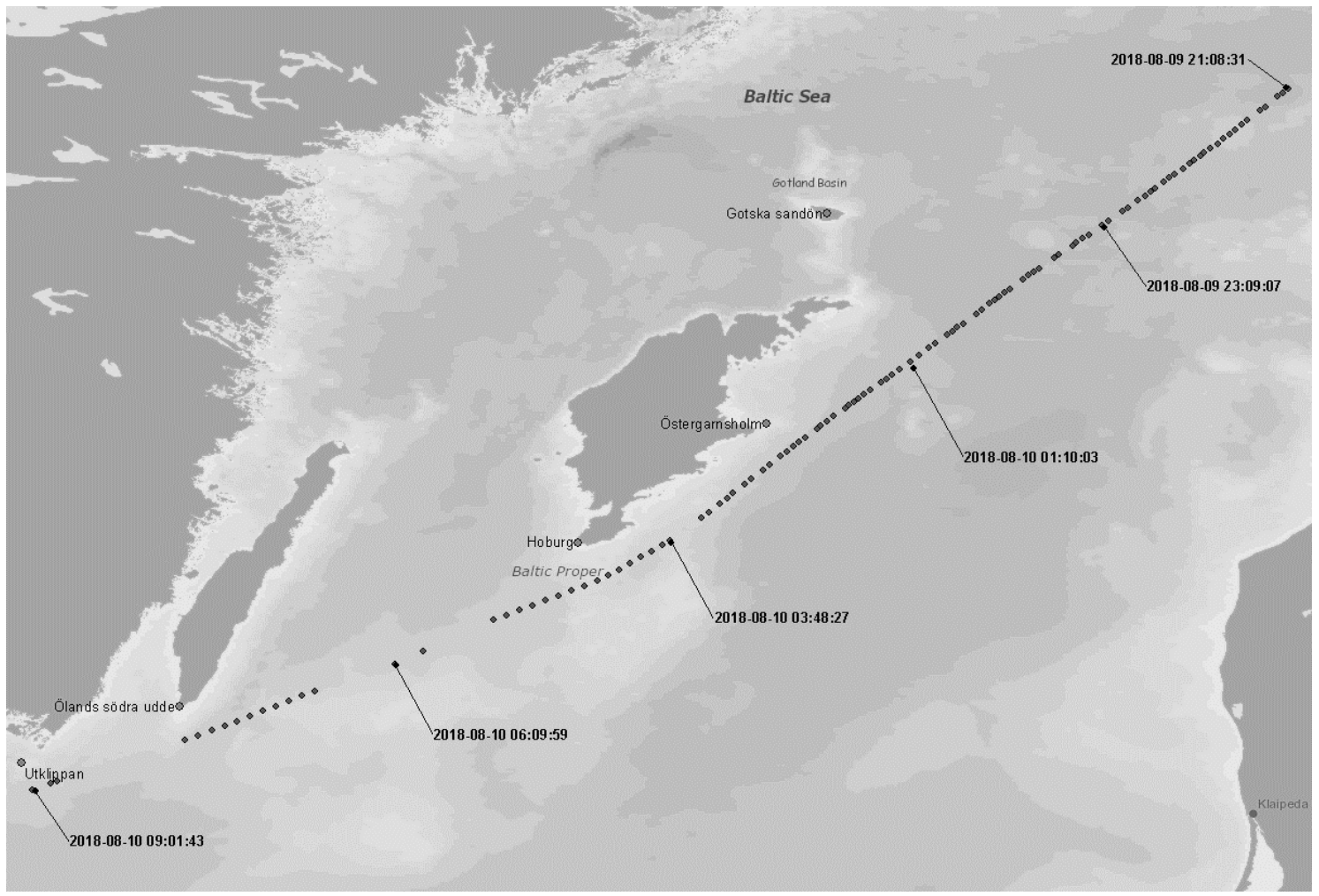

Kuva 13. Aluksen kulkema visualisoitu reitti tarkastelulegillä (@ BSH, Kristina Deichnik)

Alukselta tallennettu nopeusprofiili (kuva 14) vahvistaa nopeuden säilyneen suhteellisen vakiona keskiarvon ja mediaanin ollessa 22,2 solmua, pienimmän tallentuneen nopeuden ollessa 21,7 ja suurimman 22,8 solmua. Kyseessä on aluksen normaali matkanopeus vakioreitillään.

Aluksen saavutettua tuulirintaman on konetehoa lisätty vakionopeuden säilyttämiseksi (kuva 15). Östergarnsholmin lähellä akselitehoa on nostettu noin $21000 \mathrm{~kW}$ :sta 24000 kW:iin, ja Hoburgia lähestyttäessä noin $1000 \mathrm{~kW}$ lisää kokonaistehon ollessa käännöksen jälkeen noin 25000 kW. Potkureiden tuottama työntövoima lisääntyy siis ensivaiheessa 1800-2100 kW noussen toisen vaiheen jälkeen yhteensä $2400-2800 \mathrm{~kW}$ verrattuna ennen tuulirintamaa vallitseviin olosuhteisiin olettaen potkureiden hyötysuhteen olevan 60-70\%. Potkureiden nousu on jyrkentynyt molemmilla potkureilla melko identtisesti akselitehon kasvaessa (kuva 16).

Alukselta tallennettu trimmidata on nähtävissä kuvassa 17. Tarkastelujaksolla ensimmäisten tuntien aikana tallentunut trimmi on ollut noin $-0,55 \mathrm{~m}$ :n tuntumassa vaihdellen lukualueella $-0,5 \ldots-0,6 \mathrm{~m}$. Työntötehon lisääntyessä trimmi on jonkin verran kasvanut asettuen keskimäärin 
$-0,6 \ldots-0,65$ m:n tuntumaan. Aallokon kasvaminen näkyy trimmidatassa hajonnan lisääntymisenä, tosin todennäköisesti suoraan vastaan tulevat, navakan tuulen nostattamat aallot eivät tämän kokoluokan alusta vielä merkittävästi liikuttele.

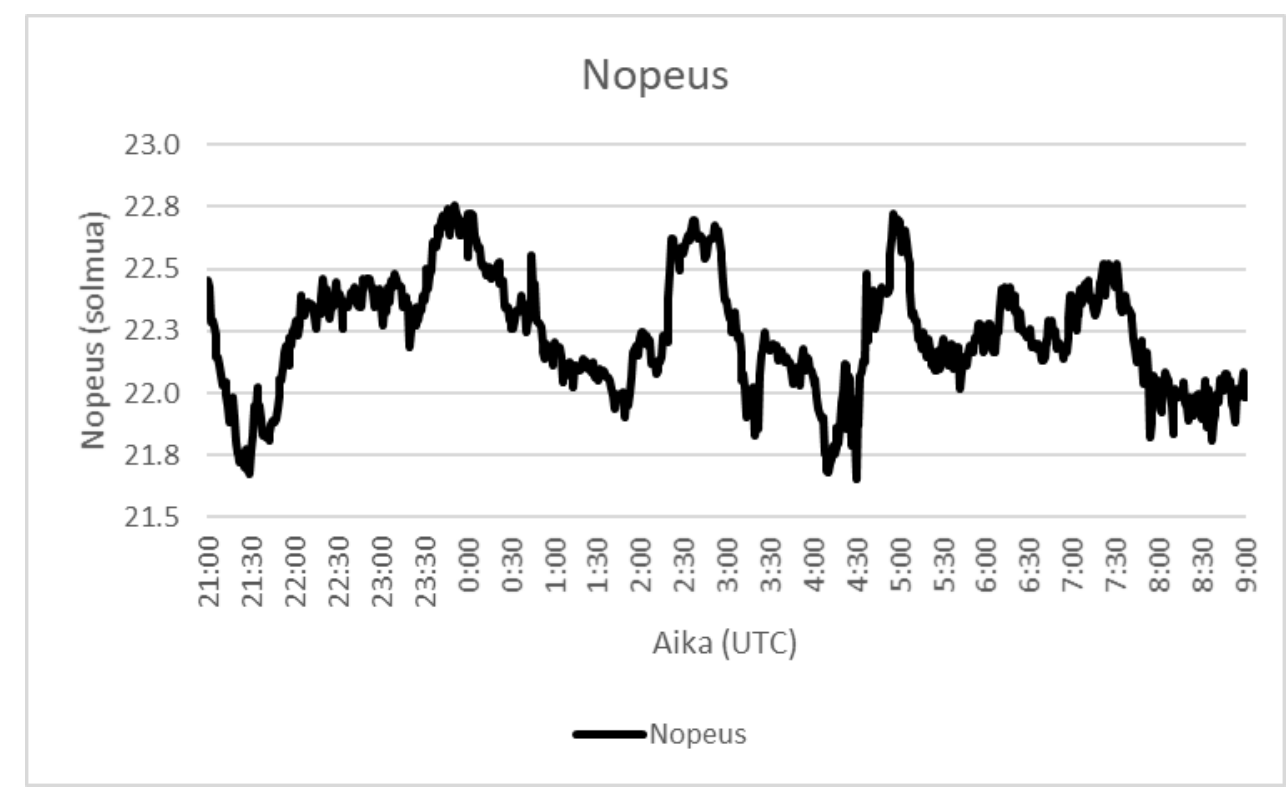

Kuva 14. Aluksen nopeusprofiili

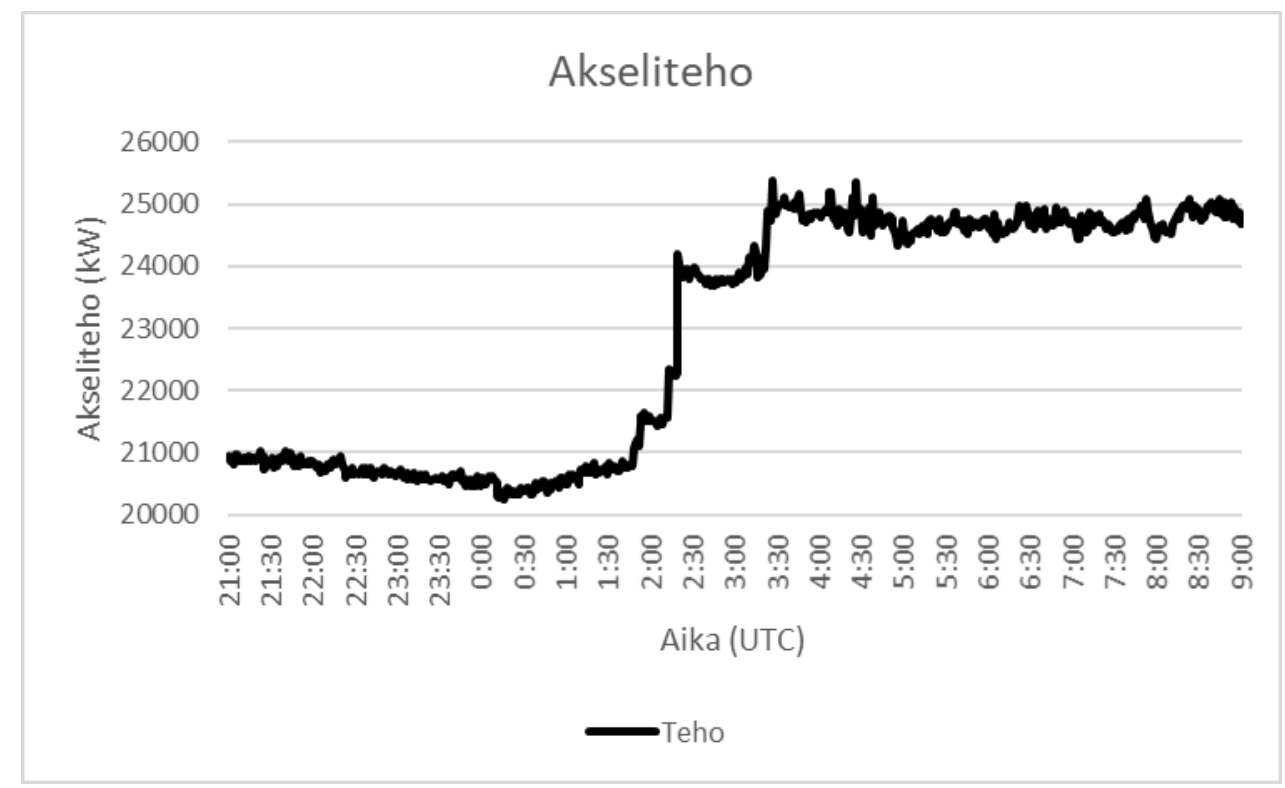

Kuva 15. Aluksen akseliteho

Alus on ollut Gotlannin itäpuolella, Östergarnsholmin lähistöllä kohdatessaan tuulirintaman ajanjaksolla 01:30-03:30 (UTC). Taulukossa 5 on esitetty legin varrella olevien rannikkosääasemien tallenteet tuulen nopeudesta $(\mathrm{m} / \mathrm{s})$ ja suunnasta $\left({ }^{\circ}\right)$. Aikaleimat (UTC) on valittu ajanjaksoille, jolloin alus on ollut sääaseman lähistöllä. Saarenmaan läntisellä rannalla sijaitsevan Ristnan sääaseman mukaan keskiyöstä keskimääräinen tuuli on ollut heikkoa $(1,4-2,0$ m/s), mikä 
vastaa 1-2 boforin tuulta. Gotska Sandön sääasemalla tuuli on ollut kohtalaista $(3,9-4,5 \mathrm{~m} / \mathrm{s}$ eli 3 boforia). Todennäköisesti avomerellä tuulen voimakkuus on rannikkoa suurempi, jolloin pohjoisella Itämerellä vallinneista tuuliolosuhteista Gotska Sandön antaa realistisemman kuvan. Toisaalta tuulen suunnan ollessa selkeästi erilainen on mahdollista, että läntisellä Itämerellä kohtalaiseksi noussut tuuli ennakoi aamulla tapahtunutta säätilan muutosta.

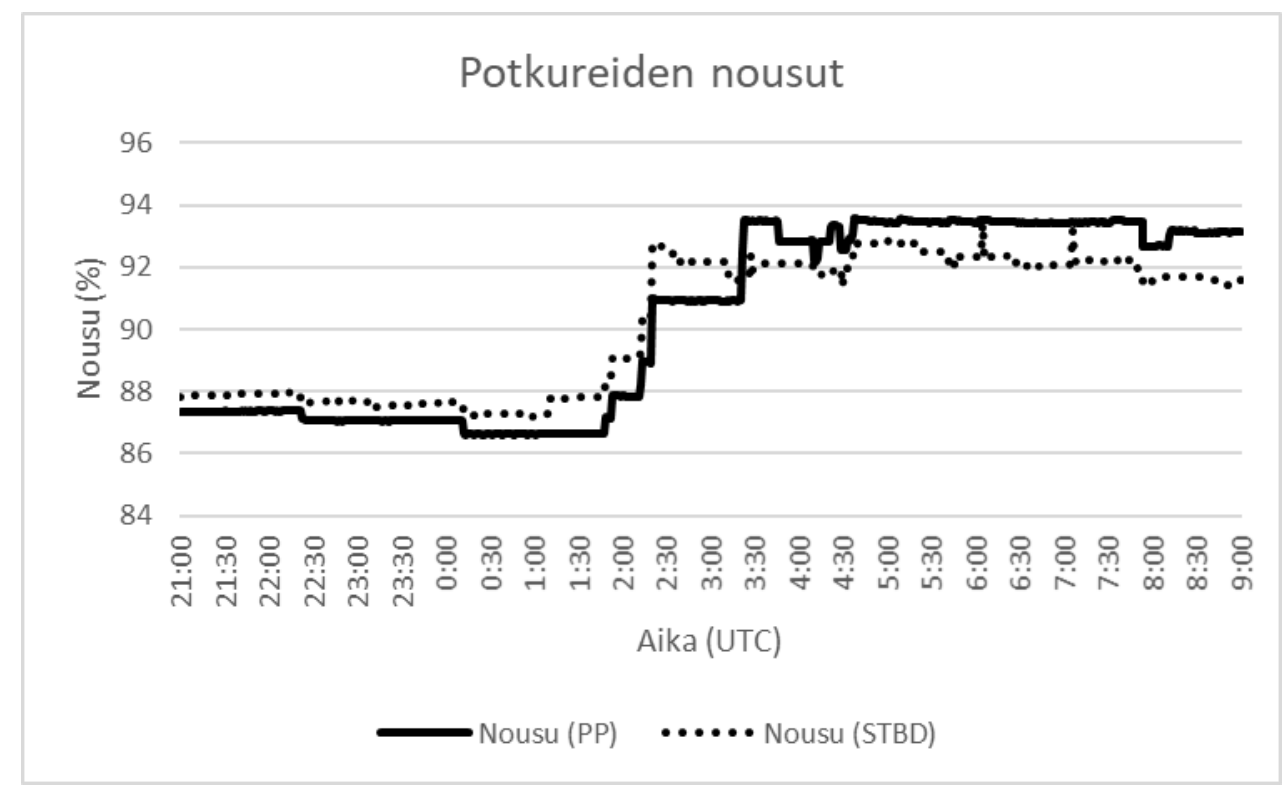

Kuva 16. Potkureiden nousut

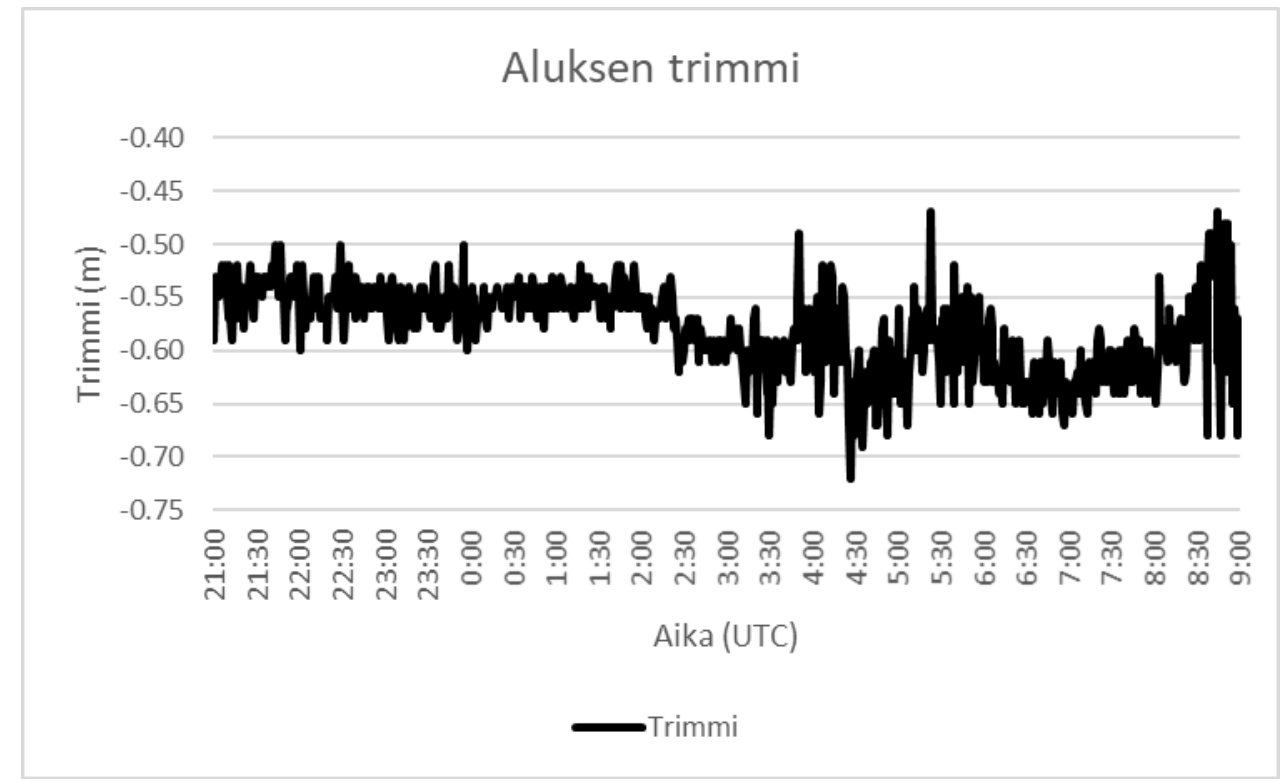

Kuva 17. Aluksen keulatrimmi

Östergarnsholmin sääasema sijaitsee Gotlannin itäpuolella olevalla pienellä saarella. Gotlannin ylitse puhaltavan tuulen suunta huomioiden Gotlanti tuuliesteenä mahdollisesti vaikuttaa Östergarnsholmin sääaseman tuloksiin. Sitä vastoin useiden kilometrien päässä rannasta oleva 
laiva kohtaa jo merenpinnan suhteen suhteellisen tasaisen tuulikentän. Työntötehon, lapakulmien ja trimmin ollessa suunnilleen vakioita tuuli- ja virtausolosuhteet ovat todennäköisesti aiheuttaneet ajanjaksolla 21:00-00:00 tapahtuneet nopeuden muutokset. Saarenmaan länsipuolella virtaus on todennäköisesti ollut (kuva 18) avomeriosuutta voimakkaampaa ollen ennusteen mukaan kuitenkin koko ajan aluksen kulkusuuntaa vastaan. Aallokon voi vallitsevissa sääolosuhteissa olettaa olevan niin pientä, ettei sillä ole tosiasiallista vaikutusta aluksen kulkuun. Tuulen voimistuminen voimakkuudeltaan 5-6 (8-12 m/s) boforin navakaksi tuuleksi (taulukko 5) aluksen sijainnin suhteen (kuva 13) on nähtävissä nopeuden tasaisena hidastumisena ajanjaksolla 00:0001:30 ennen konetehon lisäystä (kuva 15 ja kuva 16). Noin 03:30 tapahtunut Hoburgin ohittaminen ja kääntyminen Bornholmin lanelle on altistanut aluksen viimeistään pitkän pyyhkäisymatkan tuulirintamalle. Tällä lanella myös aallokko on todennäköisesti kehittymässä ollen aluksi muodoltaan jyrkkää ja tuulen jatkuessa merkitsevä aallonkorkeus todennäköisesti ylittää 2 metriä. Aluksen trimmitallenteesta on nähtävillä aaltorintaman saavuttaminen aluksen jyskimisenä, tosin kovin suuria trimmin muutoksia ei dataan kuitenkaan ole tallentunut. Tallennetta evävakaajien mahdollisesta käytöstä ei ole, mutta aallokon tullessa suoraan kohti niiden käyttö näissä olosuhteissa on epätodennäköistä.

Itämerellä ei esiinny vuorovesivirtauksia. Maapallon pyörimisliikkeen seurauksena avoveden virtaus pyrkii kääntymään kulkusuunnastaan oikealle. Koriolisvoiman ja Itämerellä vallitsevien lounaistuulten seurauksena päävirtaus kiertää Itämerta vastapäivään Suomenlahti mukaan lukien, tosin ilmiö on havaittavissa lähinnä tilastollisesti. Eri merialueilla vallitsevien pintavirtausten pääasiallisena aiheuttajana on vallitseva säätila. Tuuliolosuhteet, ilmanpaine-erot ja vesimassojen lämpötilasta johtuvat tiheyserot saavat pintaveden virtaamaan. Hyvissä olosuhteissa nämä virtaukset ovat heikkoja, yleensä selkeästi alle $10 \mathrm{~cm} / \mathrm{s}$. Saaristossa, matalikkojen tai rannikon läheisyydessä virtaukset voivat pohjan ja rantojen muodosta johtuen voimistua tästä merkittävästikin, minkä johdosta aluksen kulkua on perusteltua seurata lähinnä avomerilegeillä. Virtauksen ollessa alle $5 \mathrm{~cm} / \mathrm{s}$ (n. 0,1 solmua) sen vaikutus aluksen kulkuun on vähäinen, mutta esimerkiksi $10 \mathrm{~cm} / \mathrm{s}$ vastaa 0,2 solmua ja $30 \mathrm{~cm} / \mathrm{s}$ jo liki 0,6 solmua, jolloin virtauksen aiheuttama vaikutus esimerkiksi kuvassa 6 esitettyyn nopeus/hyötysuhdeprofiiliin on huomioitava.

Mikäli pintavirtauskenttä on suhteellisen tasainen, kuten sen voidaan olettaa olevan avomerellä, on virtauksen vaikutus aluksen kulkuun laskettavissa suoraviivaisesti. Asiaa helpottaa, mikäli alukselta on saatavissa nopeustieto veden suhteen. AIS:n tallenteisiin jäävä nopeusleima on kuitenkin useimmissa tapauksissa GPS:n määrittämä nopeus pohjan suhteen. Saksan liittovaltion liikenne- ja viestintäministeriön alaisen merenkulun ja hydrologian virasto BSH:n (Bundesamt für seeschifffart un hydrographie) tuottamat päiväkohtaiset pintavirtausmallit perustuvat vallitseviin sääolosuhteisiin ja ne soveltuvat pintavirtausten suunnan ja nopeuden ennakointiin yleisellä tarkkuudella avomeriolosuhteissa. Saaristoalueille malleja ei tuoteta ja rannikoiden lähellä merenpohjan topologia huomioiden virtausmalleihin on suhtauduttava suuremmalla varauksella. BSH:n tuottamien mallien perusteella 9.-10. elokuuta Itämerellä todennäköisesti vallitsevat virtauskentät veden pintakerroksessa (0-5 m) ovat nähtävissä kuvassa 18 .

Aamuyöllä 10. elokuuta voimistuneen lounaistuulen seurauksena malli arvioi eteläisen Itämeren merialueiden, eli Bornholmin ja itäisen Gotlannin altaiden 9. elokuuta vallinneen heterogeenisen pintavirtauskentän tasaantuvan. Meriveden inertian johdosta virtaus tosin voimistuu selkeästi tuulta hitaammin, minkä vuoksi vallitseva virtaus aluksen ympärillä aamuun sijoittuvalla mittausjaksolla todennäköisesti muistuttaa enemmän 9. elokuuta laadittua virtausennustetta, kuin 10. elokuuta luotua mallia. 
Taulukko 5. Rannikkosääasemien tuulitietoja

\begin{tabular}{|c|c|c|c|c|c|}
\hline \multicolumn{3}{|c|}{ Ristna } & \multicolumn{3}{|c|}{ Gotska sandön } \\
\hline Aika (UTC) & Suunta $\left(^{\circ}\right)$ & Nopeus (m/s) & Aika (UTC) & Suunta $\left(^{\circ}\right)$ & Nopeus $(\mathrm{m} / \mathrm{s})$ \\
\hline $19: 00$ & 141 & 1,4 & $21: 00$ & 183 & 4,5 \\
\hline 20:00 & 125 & 1,5 & 22:00 & 181 & 4,4 \\
\hline $21: 00$ & 117 & 1,6 & 23:00 & 175 & 4,2 \\
\hline $22: 00$ & 95 & 1,7 & 00:00 & 167 & 4,0 \\
\hline 23:00 & 116 & 2,0 & 01:00 & 144 & 3,9 \\
\hline \multicolumn{3}{|c|}{ Östergarnsholm } & \multicolumn{3}{|c|}{ Hoburg } \\
\hline Aika (UTC) & Suunta $\left(^{\circ}\right)$ & Nopeus (m/s) & Aika (UTC) & Suunta $\left(^{\circ}\right)$ & Nopeus $(\mathrm{m} / \mathrm{s})$ \\
\hline 00:00 & 130 & 5,0 & 03:00 & 157 & 8,1 \\
\hline 01:00 & 138 & 7,2 & 04:00 & 180 & 8,0 \\
\hline 02:00 & 147 & 7,5 & 05:00 & 176 & 5,9 \\
\hline 03:00 & 149 & 8,8 & 06:00 & 162 & 6,5 \\
\hline 04:00 & 153 & 9,1 & 07:00 & 184 & 6,5 \\
\hline \multicolumn{3}{|c|}{ Ölands södra udde } & \multicolumn{3}{|c|}{ Utklippan } \\
\hline Aika (UTC) & Suunta $\left(^{\circ}\right)$ & Nopeus (m/s) & Aika (UTC) & Suunta $\left(^{\circ}\right)$ & Nopeus $(\mathrm{m} / \mathrm{s})$ \\
\hline 06:00 & 206 & 7,7 & 07:00 & 233 & 11,9 \\
\hline 07:00 & 231 & 9,5 & 08:00 & 232 & 12,1 \\
\hline 08:00 & 237 & 10,5 & 09:00 & 238 & 10,2 \\
\hline 09:00 & 232 & 10,7 & 10:00 & 232 & 12,2 \\
\hline 10:00 & 236 & 9,9 & 11:00 & 232 & 11,5 \\
\hline
\end{tabular}

Meriympäristön olosuhteiden vaikutus aluksen kulkuvastukseen on siis merkittävä verrattuna säännöllisesti puhdistettavan pohjan likaantumisen aiheuttamaan lisävastukseen. Tämän voi todeta taulukosta 6 , missä on esitetty laskennallisia kulkuvastuksen tehoja eri nopeuksilla, pohjan karheudella ja vastatuulella. Taulukosta nähdään, että pohjan painotetun karheuden kasvaessa 150 $\mu \mathrm{m}$ :stä $250 \mu \mathrm{m}$ :n laskennallinen kulkuvastus lisääntyy 2,8-2,9\%, jolloin tehoero olisi 362-413 $\mathrm{kW}$. Verrattaessa tätä $5 \mathrm{~m} / \mathrm{s}$ puhaltaman vastatuulen aiheuttamaan vastukseen (aluksen ilmanvastuskerroin 0,7 , ilman tiheys $1,2 \mathrm{~kg} / \mathrm{m}^{3}$ ja otsapinta-ala $1000 \mathrm{~m}^{2}$ ) puhutaan jo yli kolminkertaisesta erosta.

Toisaalta hyvissä olosuhteissa (tuuli 1-2 boforia, virtaukset selkeästi alle $5 \mathrm{~cm} / \mathrm{s}$, ei merkittävää aallokkoa) tallentuneessa datassa pohjan likaantumisesta seuraava kulkuvastuslisä on suuruusluokaltaan verrattavissa muihin meriolosuhteista riippuviin häiriötekijöihin, mikä helpottaa vaikutuksen havaitsemista. Asiaa helpottaa se, että pohjan likaantumisesta aiheutuva lisävastus kehittyy kumulatiivisesti ajan funktiona siinä missä esimerkiksi tuuliolosuhteet vaihtelevat jatkuvasti. Tällaisen tilastollisen big data-ongelman ratkaisemiseksi yksi soveltuva työkalu ovat 
Bayes-verkot, mitkä tarjoavat mielenkiintoisen työvälinepaketin datan riippuvuuksien analysointiin. Esimerkiksi Naiivi Bayes -menetelmällä voidaan ratkaista luokitteluongelmia, missä malliin syötettävien muuttujien arvojen määrittäminen on haastavaa toteuttaa luotettavasti. Tällaisissa tilanteissa verkkorakenteen riippumattomuusolettama eri dataluokkien välillä voi hyvinkin tuottaa suhteellisen luotettavan tuloksen. Menetelmävalintojen tarkoitus on kuitenkin tuottaa tietoa, jonka perusteella voidaan tehdä johtopäätöksiä, onko oleellisempaa työkalun toiminnan ja käytön kannalta pyrkiä saamaan laadukkaampaa dataa päätöksenteon tueksi vai muokata esitettyä teoreettista viitekehystä laskennallisesti tarkempaan suuntaan.
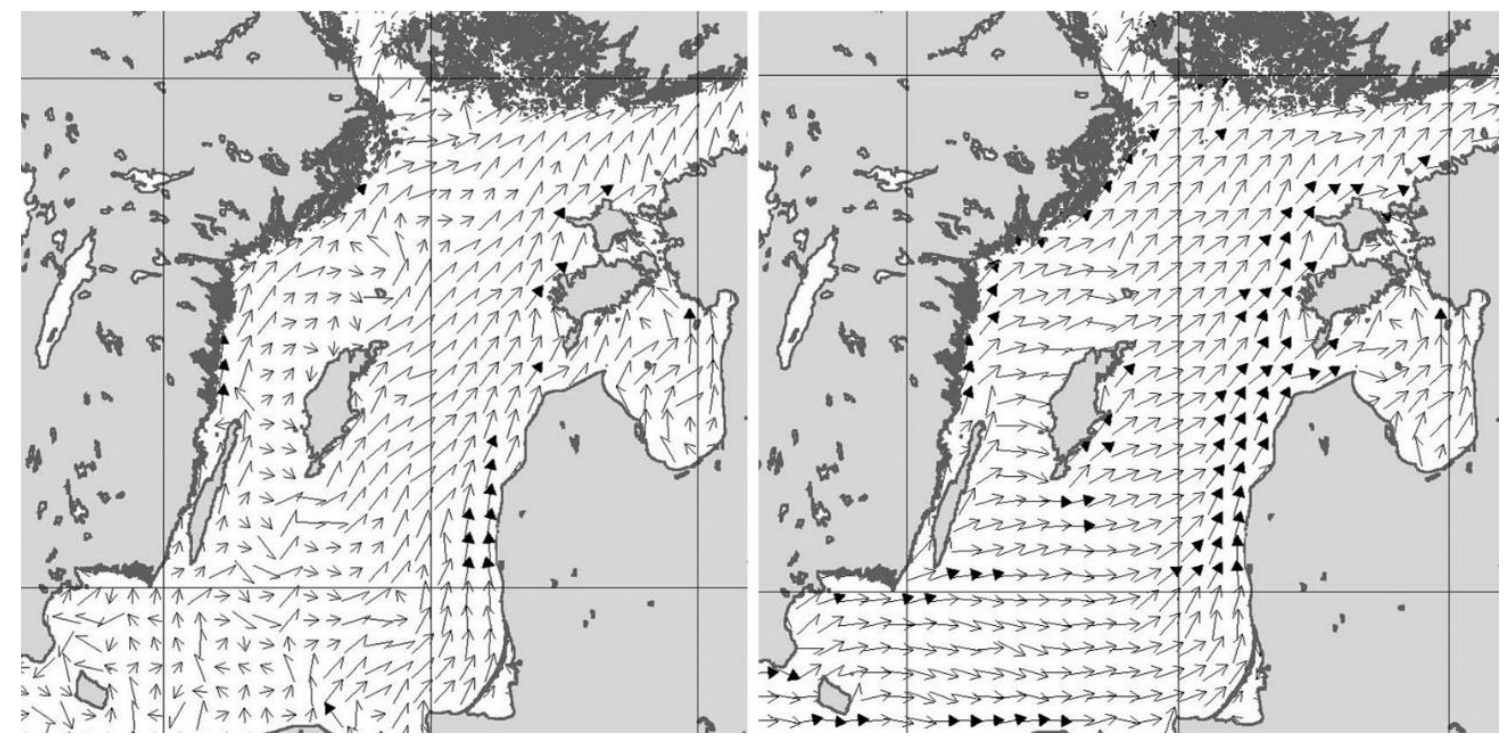

\begin{tabular}{cl}
\hline Symboli & Virtausnopeus (syvyysalue $0-5 \mathrm{~m}$ ) \\
\hline 7 & $0,1-2,5 \mathrm{~cm} / \mathrm{s}$ \\
$\longrightarrow$ & $2,5-5,0 \mathrm{~cm} / \mathrm{s}$ \\
$\longrightarrow$ & $5,0-10,0 \mathrm{~cm} / \mathrm{s}$ \\
$\longrightarrow$ & $10,0-30,0 \mathrm{~cm} / \mathrm{s}$ \\
\hline
\end{tabular}

Kuva 18. Itämeren virtausennusteet 9.8 ja 10.8 (@ BSH).

\section{Yhteenveto}

Tässä artikkelissa on käsitelty COMPLETE-hankkeessa kehitettävää optimointityökalua varten alusten kulkuvastusten mallinnusmenetelmiä ja verrattu niiden antamia tuloksia operoivalta alukselta tallennettuun dataan. Tässä tutkimuksessa sovellettu kulkuvastusmalli seuraa pääsääntöisesti ITTC:n hyväksymiä menetelmiä kulkuvastusten analyyttisestä mallintamisesta. Kitkavastuksen mallintamiseen on sovellettu lisäksi Grigsonin esittämää yhtälöä. Tässä muodossa esitettynä malli sisältää hydrostaattisista komponenteista kitka- ja aaltovastuksen, pohjan karheusvaikutuksen, huomioi bulbikeulan ja arvioi ohjailuvastuksen. Aluksen painumaa malli ei tässä muodossa huomioi, mutta operoitaessa Frouden syvyyslukuun perustuen riittävän syvässä vedessä, on sen vaikutus vähäinen. Tuuliolosuhteiden ja virtausten vaikutus huomioidaan karkeasti. 
Aluksen mitat, lastaus ja nopeus huomioiden saadaan mallilla laskettua aluksen teoreettinen kulkuvastus. Verrattaessa tätä funktiota akseleiden torsiometrien tuottamiin tallenteisiin, saadaan aluksen teoreettinen hyötysuhde, mikä käytännössä sisältää myös sääolosuhteiden muutokset. Pohjan likaantuminen kasvattaa kulkuvastusta kumulatiivisesti ajan funktiona, jolloin se poikkeaa luoteeltaan muista vastukseen muuttuvista tekijöistä ja sen havaitseminen tilastollisesti tämän vuoksi helpottuu. Tässä paperissa esitetty lähestymistapa on valittu sen sovellettavuuden takia: Laivojen elinkaari on pitkä ja varustamoiden tai viranomaisten mahdollisuudet tehdä tarkempia analyysejä alustensa hydrodynamiikasta ovat rajalliset. Lähestymistapa, mikä perustuu näiden tahojen saatavissa oleviin lähtöarvoihin ja aluksilta tallennettavissa olevaan dataan, on oleellista projektin tavoitteita ajatellen.

Menetelmän herkkyyttä erityisesti tuuli-, virtaus ja aalto-olosuhteiden suhteen pohditaan monesta eri näkökulmasta. Avomerellä meren pintavirtaukset ovat tavallisesti suhteellisen tasaisia ja pienemmät aallot eivät suuren laivan liikkeisiin juurikaan vaikuta. Tuuliolosuhteet ovat sitä vastoin haastavammat arvioida luotettavasti, sillä rannikkoasemien antama tuulidata voi poiketa avomeren tuuliolosuhteista joissain tapauksissa merkittävästikin ja tuuliolosuhteet voivat olla hyvinkin puuskaisia ja muuntua suhteellisen lyhyessä ajassa. Laivan oma sääasema on tavallisesti mastossa, jolloin tuuliolosuhteet lähes 50 metrin korkeudessa meren pinnasta voivat olla selkeästi voimakkaampia verrattuna korkeuksiin, missä suurin osa aluksen tuulivastuksesta muodostuu. Lisäksi aluksen runko aiheuttaa tuulikenttään voimakasta turbulenssia, minkä takia alukselta tallennettuun tuulidataan on suhtauduttava varauksellisesti. Toisaalta teoreettisen hyötysuhteen tarkasteleminen edesauttaa osaltaan myös tätä ongelmaa: Hyötysuhdekäyrän muutokset nopeuden ja konekäskyjen säilyessä suunnilleen vakioina usein indikoivat vallitsevien tuuliolosuhteiden muutoksia, jolloin pohjan likaantumisen vaikutusten havainnointiin voidaan valita data, jolloin tuuliolosuhteet ovat tarkastelua ajatellen mahdollisimman suotuisat. Näiden seikkojen vuoksi seuraava vaihe optimointityökalun kehityksessä on tilastollisten menetelmien hyödyntäminen datan analysoimiseksi.

Taulukko 6. Pohjan karheuden ja tuulen laskennallinen vaikutus kulkuvastukseen

\begin{tabular}{|c|c|c|c|c|}
\hline $\begin{array}{l}\text { Nopeus } \\
\text { (solmua) }\end{array}$ & $\begin{array}{l}\text { Kulkuvastuksen } \\
\text { teho }(\mathrm{kW}) \\
(0 \mathrm{~m} / \mathrm{s}, 150 \mu \mathrm{m})\end{array}$ & $\begin{array}{l}\text { Kulkuvastuksen } \\
\text { teho }(\mathrm{kW}) \\
(0 \mathrm{~m} / \mathrm{s}, 250 \mu \mathrm{m})\end{array}$ & $\begin{array}{l}\text { Kulkuvastuksen } \\
\text { teho }(\mathrm{kW}) \\
(5 \mathrm{~m} / \mathrm{s}, 150 \mu \mathrm{m})\end{array}$ & $\begin{array}{l}\text { Kulkuvastuksen } \\
\text { teho }(\mathrm{kW}) \\
(5 \mathrm{~m} / \mathrm{s}, 250 \mu \mathrm{m})\end{array}$ \\
\hline 22,0 & 12542 & $12904(+2,9 \%)$ & $13758(+9,7 \%)$ & $14120(+12,6 \%)$ \\
\hline 22,2 & 12985 & $13357(+2,9 \%)$ & $14219(+9,5 \%)$ & $14591(+12,4 \%)$ \\
\hline 22,4 & 13445 & $13827(+2,8 \%)$ & $14698(+9,3 \%)$ & $15079(+12,2 \%)$ \\
\hline 22,6 & 13923 & $14315(+2,8 \%)$ & $15193(+9,1 \%)$ & $15586(+11,9 \%)$ \\
\hline 22,8 & 14419 & $14822(+2,8 \%)$ & $15708(+8,9 \%)$ & $16111(+11,7 \%)$ \\
\hline 23,0 & 14935 & $15348(+2,8 \%)$ & $16242(+8,8 \%)$ & $16656(+11,5 \%)$ \\
\hline
\end{tabular}




\section{Kiitokset}

Lausumme kiitokset COMPLETE-hankkeen päärahoittajalle (Interreg Baltic Sea Region / EU) ja hankkeen pääkoordinaattorina toimivalle Meriturvallisuuden ja -liikenteen tutkimuskeskus Merikotkan COMPLETE-työryhmälle. Lisäksi kiitokset kuuluvat tämän artikkelin valmistumiseen vaikuttaneille COMPLETE-hankkeen yhteistyökumppaneille; Marko Piispalle ja Mikko Nykäselle KymiLabs:sta; Annukka Lehikoiselle ja Inari Helleelle Helsingin yliopistosta; Lena Granhagille ja Dinis Oliveiralle Chalmers-yliopistosta; Annika Krutwalle, Katja Broegille ja Kristina Deichnikille BSH:Ita; Suomen, Ruotsin ja Viron ilmatieteen laitoksille; Anna-Liisa Perttilälle sekä tutkimukseen osallistuneelle laivaväelle Finnlinesiltä.

\section{Viitteet}

[1] Completing management options in the Baltic Sea Region to reduce risk of invasive species introduction by shipping.

http://www.balticcomplete.com [Viitattu 7.1.2019]

[2] H. Ojaveer, B.S. Galil, J.T Carlton, H. Alleway, P. Goulletquer, M. Lehtiniemi, A. Marchini, W. Miller, A. Occhipinti-Ambrogi, M. Perharda, G.M Ruiz, S.L.

Williams, A. Zaiko. Historical baselines in marine bioinvasions: Implications for policy and management. PLoS One, 13(8), e0202383, 2018.

https://doi.org/10.1371/journal.pone.0202383

[3] M. Lehtiniemi, H. Ojaveer, M. David, B.S. Galil, S. Gollasch, C. McKenzie, D. Minchin, A.Occhipinti-Ambrogi, S. Olenin, J. Pederson. Dose of truth -

Monitoring marine non-indigenous species to serve legislative requirements.

Marine policy, 54(1): 26-35, 2015. https://doi.org/10.1016/j.marpol.2014.12.015

[4] International maritime organization. International convention for the control and management of ships' ballast water and sediments. IMO, London, 2004.

[5] SopS 38/2017. Alusten painolastivesien ja sedimenttien valvontaa ja käsittelyä koskeva kansainvälinen yleissopimus, 2004.

[6] BIMCO. Hull fouling clause for time charter parties (updated 16 July 2015), special circular no 3, 2013. https:www.bimco.org/contracts-and-clauses/bimcoclauses

[7] International maritime organization. International convention on the control of harmful anti-fouling systems on ships. IMO, London, 2001.

[8] International maritime organization. Guidelines for the control and management of ships' biofouling to minimize the transfer of invasive aquatic species. Resolution marine environment protection committee, 207(62), IMO, London, 2011.

[9] F.R. Brady, I.L. Singer. Mechanical factors favoring release from fouling release coatings. Biofouling, 15(1-3):73-81, 2000. https://doi.org/10.1080/08927010009386299

[10] A.F. Molland, S.R. Turnock, D.A. Hudson. Ship resistance and propulsion. Practical estimation of ship propulsive power. Cambridge university press, Cambridge, 2011. 
[11] J.F.C. Conn, H. Lackenby, W.P. Walker. Resistance experiments on the Lucy Ashton. Trans INA 95:350-436, 1953.

[12] K. Tokunaga, E. Baba. Approximate calculation of ship frictional resistance increase due to surface roughness. Journal of the society of naval architects of Japan, 152:55-61, 1982. https://doi.org/10.2534/jjasnaoe1968.1982.152_55

[13] D. Oliveira. The enemy below - Adhesion and friction of ship hull fouling. Chalmers university of technology, Gothenburg, 2017.

[14] W. Froude. Experiments on the surface-friction experienced by a plane moving through water (1872). British Association for the advancement of science. The collected papers of William Froude, Institution of naval architects, 138-146, 1955.

[15] W. Froude. Report to the lords commissioners of the admiralty on experiments for the determination of the frictional resistance of water on a surface, under various conditions. Performed at Chelston cross, under the authority of their lordships, 44th Report, 1874.

[16] W. McEntee. Variation of frictional resistance of ships with condition of wetted surface. Transactions, The society of naval architects and marine engineers, 24:37-42, 1916. https://doi.org/10.1111/j.1559-3584.1916.tb00632.x

[17] G. Kempf. On the effect of roughness on the resistance of ships. Transactions of INA, 79:109-119, 1937.

[18] J. Benson, J. Ebert, T. Beery investigation in the NACA tank of the effect of immersion in salt water on the resistance of plates coated with different shipbottom paints. NACA Memorandum Report C\&R, C-S19-1(3), 1938.

[19] S. Watanabe, N. Nagamatsu, K. Yokoo, Y. Kawakami. The augmentation in frictional resistance due to slime. Journal of Kansai society of naval architects, 131:45-53, 1969.

[20] G. Loeb, D. Laster, T. Gracik. The influence of microbial fouling films on hydrodynamic drag of rotating discs. In: J.D. Costlow, R. Tipper (editors), Marine biodeterioration: an interdisciplinary study. Naval Institute Press, Annapolis, 8894, 1984.

[21] A. Lewkowicz, D. Das. Turbulent boundary layers on rough surfaces with and without a pliable overlayer: A simulation of marine fouling. International shipbuilding progress, 33:174-186, 1986. https://doi.org/10.3233/ISP-1986-3338601

[22] M.P. Schultz, G. Swain. The effect of biofilms on turbulent boundary layers. Journal of fluids engineering, 121:44-51, 1999. https://doi.org/10.1115/1.2822009

[23] M.P. Schultz. Turbulent boundary layers on surfaces covered with filamentous algae. Journal of fluids engineering, 122:357-363, 2000. https://doi.org/10.1115/1.483265

[24] M.P. Schultz. Frictional resistance of antifouling coating systems. Journal of fluids engineering, 126:1039-1047, 2004.

https://doi.org/10.1115/1.1845552 
[25] L.E. Johansson. The local effect of hull roughness on skin friction. Royal institute of naval architects' transactions, 127:187-201, 1984.

[26] M. Leer-Andersen, L. Larsson. An experimental/numerical approach for evaluating skin friction on full-scale ships with surface roughness. Journal of marine science and technology, 8:26-36, 2003. https://doi.org/0.1007/s10773-003-0150-y

[27] J.P. Monty, E. Dogan, R. Hanson, A.J. Scardino, B. Ganapathisubramani, N. Hutchins. An assessment of the ship drag penalty arising from light calcareous tubeworm fouling. Biofouling, 32(4):451-464, 2016. https://doi.org/10.1080/08927014.2016.1148140

[28] M.P. Schultz, J.A. Bendick, E.R. Holm, W.M. Hertel. Economic impact of biofouling on a naval surface ship. Biofouling, 27(1):87-98, 2011. https://doi.org/10.1080/08927014.2010.542809

[29] T. Munk, D. Kane, D.M Yebra. The effects of corrosion and fouling on the performance of ocean-going vessels: a naval architectural perspective. In: Advances in marine antifouling coatings and technologies. Woodhead publishing limited, Oxford, 2009. https://doi.org/10.1533/9781845696313.1.148

[30] M.P. Schultz. Effects of coating roughness and biofouling on ship resistance and powering. Biofouling, 23:331-334, 2007. https://doi.org/10.1080/08927010701461974

[31] K.A. Flack, M.P. Schultz. Review of hydraulic roughness scales in the fully rough regime. Journal of fluids engineering, 132(4):041203-041203-10, 2010. https://doi.org/10.1115/1.4001492

[32] O. Turan, Y.K. Demirel, S. Day, T. Tezdogan. Experimental determination of added hydrodynamic resistance caused by marine biofouling on ships. $6^{\text {th }}$ European transport research conference proceedings, 14:1649-1658, 2016 https://doi.org/10.1016/j.trpro.2016.05.130

[33] Y.K. Demirel, D. Uzun, Y. Zhang, H.C. Fang, A. H. Day, O. Turan. Effect of barnacle fouling on ship resistance and powering. Biofouling, 33(10):819-834, 2017. https://doi.org/10.1080/08927014.2017.1373279

[34] Y.K. Demirel, O. Turan, A. Incecik. Predicting the effect of biofouling on ship resistance using CFD. Applied ocean research, 62:100-118, 2017. https://doi.org/10.1016/j.apor.2016.12.003

[35] Helsingin komissio. http://www.helcom.fi. Viitattu [7.1.2019].

[36] H.O. Kristensen, H. Psaraftis. Prediction of resistance and propulsion power of Ro-Ro ships. Technical university of Denmark, project no 2014-122, WP2.3, report no. 1, 2016.

[37] H.O. Kristensen, M. Lützen. Prediction of resistance and propulsion power of ships. Technical university of Denmark, project no 2010-56, WP2, report no. 4, 2013.

[38] E.V. Lewis (ed.). Principles of naval architecture. Volume II: Resistance, propulsion and vibration. The society of naval architects and marine engineers, New Jersey, 1988.

[39] J. Matusiak. Laivan propulsio. Teknillinen korkeakoulu, Espoo, 2005. 
[40] J.S. Carlton. Marine propellers and propulsion. Butterworth-Heinemann, London, 1994.

[41] C.W.B. Grigson. An accurate smooth friction line for use in performance prediction. Transactions of the royal institution of naval architects, 135:149-162, 1993.

[42] C.W.B. Grigson, A planar friction algorithm and its use in analyzing hull resistance. Transactions of the royal institution of naval architects, 142:76-115, 2000.

[43] S.A. Harvald. Resistance and propulsion of ships. John Wiley \& Sons, New York, 1983.

[44] H.E. Guldhammer, S.A Harvald. Ship resistance - Effect of form and principal dimensions. Akademisk forlag, Copenhagen, 1974.

[45] S. Paukkeri. Nopeusrajoitukset alusliikenteen ympäristövaikutusten, turvallisuuden ja sujuvuuden kannalta Vuosaaren väylällä. Liikenneviraston tutkimuksia ja selvityksiä 50, 2010.

[46] PIANC. Guidelines for managing wake wash from high-speed vessels. Report of the working group 41 of the maritime navigation commission, 2003.

[47] T. Soomere. Nonlinear ship wake waves as a model of rogue waves and a source of danger to the coastal environment: A review. Oceanologia, 48:185-202, 2006.

[48] G. van Oortmerssen. A power prediction method and its application to small ships. International shipbuilding progress, 18:397-415, 1971. https://doi.org/10.3233/ISP-1971-1820701

[49] S.M. Calisal, D. McGreer. A resistance study on a systematic series of low L/B vessels. Marine technology, 30:286-296, 1993.

[50] E. Tupper. Introduction to naval architecture. Butterworth-Heinemann, Oxford, 1996.

[51] A.M. Kracht. Design of bulbous bows. The transactions of the society of naval architects and marine engineers collection, 78:197-217, 1978.

[52] D. Oliveira, A.I. Larsson, L. Granhag. Effect of ship hull form on the resistance penalty from biofouling. Biofouling, 34(3):262-272, 2018. https://doi.org/10.1080/08927014.2018.1434157

[53] R.L. Townsin. The ship hull fouling penalty. Biofouling, vol. 19(S1):9-15, 2003. https://doi.org/10.1080/0892701031000088535

[54] O.G. Akinlade. Effects of surface roughness on the flow characteristics in a turbulent boundary layer. University of Saskatchewan, Saskatoon, 2005.

[55] M.P. Schultz, K.A. Flack. The rough-wall turbulent boundary layer from the hydraulically smooth to the fully rough regime. Journal of fluid mechanics, 580:381-405, 2007. https://doi.org/10.1017/S0022112007005502

[56] M.P. Schultz, J.A. Finlay, M.E. Callow, J.A. Callow. Three models to relate detachment of low form fouling at laboratory and ship scale. Biofouling, 19:1726, 2003.

https://doi.org/10.1080/0892701031000089516 
Elias Altarriba

Kaakkois-Suomen ammattikorkeakoulu

Pääskysentie 1, 48220 Kotka

elias.altarriba@xamk.fi 